\title{
The role of dew as a night-time reservoir and morning source for atmospheric ammonia
}

\author{
Gregory R. Wentworth ${ }^{1}$, Jennifer G. Murphy ${ }^{1}$, Katherine B. Benedict ${ }^{2}$, Evelyn J. Bangs ${ }^{2}$, and Jeffrey L. Collett Jr. ${ }^{2}$ \\ ${ }^{1}$ Department of Chemistry, University of Toronto, 80 St. George Street, M5S 3H6, Toronto, ON, Canada \\ ${ }^{2}$ Department of Atmospheric Science, Colorado State University, 3915 W. Laporte Ave., 80523, Fort Collins, CO, USA
}

Correspondence to: Jennifer G. Murphy (jmurphy@ chem.utoronto.ca)

Received: 24 February 2016 - Published in Atmos. Chem. Phys. Discuss.: 7 March 2016

Revised: 20 May 2016 - Accepted: 1 June 2016 - Published: 15 June 2016

\begin{abstract}
Several field studies have proposed that the volatilization of $\mathrm{NH}_{3}$ from evaporating dew is responsible for an early morning pulse of ammonia frequently observed in the atmospheric boundary layer. Laboratory studies conducted on synthetic dew showed that the fraction of ammonium $\left(\mathrm{NH}_{4}^{+}\right)$released as gas-phase ammonia $\left(\mathrm{NH}_{3}\right)$ during evaporation is dependent on the relative abundances of anions and cations in the dew. Hence, the fraction of $\mathrm{NH}_{3}$ released during dew evaporation $\left(\operatorname{Frac}\left(\mathrm{NH}_{3}\right)\right)$ can be predicted given dew composition and $\mathrm{pH}$. Twelve separate ambient dew samples were collected at a remote high-elevation grassland site in Colorado from 28 May to 11 August 2015. Average $\left[\mathrm{NH}_{4}^{+}\right]$and $\mathrm{pH}$ were $26 \mu \mathrm{M}$ and 5.2 respectively and were on the lower end of dew $\left[\mathrm{NH}_{4}^{+}\right]$and $\mathrm{pH}$ observations reported in the literature. Ambient dew mass (in $\mathrm{g} \mathrm{m}^{-2}$ ) was monitored with a dewmeter, which continuously measured the mass of a tray containing artificial turf representative of the grass canopy to track the accumulation and evaporation of dew. Simultaneous measurements of ambient $\mathrm{NH}_{3}$ indicated that a morning increase in $\mathrm{NH}_{3}$ was coincident in time with dew evaporation and that either a plateau or decrease in $\mathrm{NH}_{3}$ occurred once the dew had completely evaporated. This morning increase in $\mathrm{NH}_{3}$ was never observed on mornings without surface wetness (neither dew nor rain, representing one-quarter of mornings during the study period). Dew composition was used to determine an average $\operatorname{Frac}\left(\mathrm{NH}_{3}\right)$ of 0.94 , suggesting that nearly all $\mathrm{NH}_{4}^{+}$is released back to the boundary layer as $\mathrm{NH}_{3}$ during evaporation at this site. $\mathrm{An}$ average $\mathrm{NH}_{3}$ emission of $6.2 \mathrm{ng} \mathrm{m}^{-2} \mathrm{~s}^{-1}$ during dew evaporation was calculated using total dew volume $\left(V_{\text {dew }}\right)$ and evaporation time $\left(t_{\text {evap }}\right)$ and represents a significant morning flux in a non-fertilized grassland. Assuming a boundary
\end{abstract}

layer height of $150 \mathrm{~m}$, the average mole ratio of $\mathrm{NH}_{4}^{+}$in dew to $\mathrm{NH}_{3}$ in the boundary layer at sunrise is roughly $1.6 \pm 0.7$. Furthermore, the observed loss of $\mathrm{NH}_{3}$ during nights with dew is approximately equal to the observed amount of $\mathrm{NH}_{4}^{+}$ sequestered in dew at the onset of evaporation. Hence, there is strong evidence that dew is both a significant night-time reservoir and strong morning source of $\mathrm{NH}_{3}$. The possibility of rain evaporation as a source of $\mathrm{NH}_{3}$, as well as dew evaporation influencing species of similar water solubility (acetic acid, formic acid, and HONO), is also discussed. If release of $\mathrm{NH}_{3}$ from dew and rain evaporation is pervasive in many environments, then estimates of $\mathrm{NH}_{3}$ dry deposition and $\mathrm{NH}_{x}\left(\equiv \mathrm{NH}_{3}+\mathrm{NH}_{4}^{+}\right)$wet deposition may be overestimated by models that assume that all $\mathrm{NH}_{x}$ deposited in rain and dew remains at the surface.

\section{Introduction}

Ammonia $\left(\mathrm{NH}_{3}\right)$ is the most prevalent alkaline gas in the atmosphere and has important implications for both climate and air quality (Seinfeld and Pandis, 2006). For instance, $\mathrm{NH}_{3}$ partitions to acidic fine particulate matter $\left(\mathrm{PM}_{2.5}\right.$, aerosol with diameter $<2.5 \mu \mathrm{m}$ ) to form particulate-phase ammonium $\left(\mathrm{NH}_{4}^{+}\right)$, which alters aerosol properties such as hygroscopicity (Petters and Kreidenweis, 2007) and scattering efficiency (Martin et al., 2004). High atmospheric loadings of $\mathrm{PM}_{2.5}$ can lead to adverse health effects (Pope et al., 2002) as well as reduced visibility. $\mathrm{NH}_{3}$ is primarily emitted to the atmosphere through agricultural activities (e.g. fertilization, animal husbandry) in addition to natural sources (e.g. soil, vegetation, oceans, volcanoes, wild- 
fires) and other anthropogenic sources (vehicles and industry) (Reis et al., 2009). Deposition of atmospheric $\mathrm{NH}_{x}$ $\left(\equiv \mathrm{NH}_{3}+\mathrm{NH}_{4}^{+}\right)$can cause eutrophication and soil acidification in sensitive ecosystems (Krupa, 2003). Hence, there is great interest in being able to accurately model sources, sinks, and reservoirs of $\mathrm{NH}_{x}$.

A common feature in the diurnal cycle of atmospheric $\mathrm{NH}_{3}$ mixing ratios is a morning increase or "spike" that typically occurs around 07:00-10:00 LT. Frequently observed in many environments, current hypotheses to explain the morning $\mathrm{NH}_{3}$ increase include dew evaporation (Gong et al., 2011; Wentworth et al., 2014; Wichink Kruit et al., 2007), plant and/or soil emissions (Bash et al., 2010; Ellis et al., 2011), mixing down of $\mathrm{NH}_{3}$-rich air during the break-up of the nocturnal boundary layer (Walker et al., 2006), and automobile emissions during morning rush hour (Gong et al., 2011; Löflund et al., 2002; Nowak et al., 2006; Whitehead et al., 2007). Several field studies have indicated that $\mathrm{NH}_{3}$ desorption from microscopic water films on leaf surfaces can yield significant fluxes (Burkhardt et al., 2009; Flechard et al., 1999; Neirynck and Ceulemans, 2008; Sutton et al., 1998); therefore, it is reasonable to suggest that macroscopic dew droplets have the same effect. Wentworth et al. (2014) observed a larger morning increase following nights with high relative humidity (RH, a surrogate for dew) and Wichink Kruit et al. (2007) found increasing upward fluxes as soon as the canopy began to dry as measured by a leaf wetness sensor.

Dew generally forms during calm, clear nights when radiative cooling of the surface favours the condensation of water (Richards, 2004). Formation typically starts shortly after sunset and lasts until sunrise when surface heating and a drop in RH initiate evaporation. Over the last 5 decades, several dozen studies have characterized dew composition and have found that $\mathrm{NH}_{4}^{+}$is a ubiquitous constituent of dew and, in some environments, can be the most abundant cation (e.g. Polkowska et al., 2008; Wagner et al., 1992; Yaalon and Ganor, 1968; Yadav and Kumar, 2014). Average $\left[\mathrm{NH}_{4}^{+}\right]$reported in dew ranges from $25 \mu \mathrm{M}$ (Lekouch et al., 2010) to $1600 \mu \mathrm{M}$ (Yadav and Kumar, 2014). The composition of dew is primarily controlled by dissolution of water-soluble gases (e.g. $\mathrm{NH}_{3}, \mathrm{HNO}_{3}, \mathrm{CO}_{2}, \mathrm{SO}_{2}$ ) and deposition of coarse mode particles (larger than $\mathrm{PM}_{2.5}$ but smaller than $10 \mu \mathrm{m}$ in diameter) (Takeuchi, 2003).

Field-scale models typically allow $\mathrm{NH}_{3}$ to only deposit on leaf cuticles (i.e. it cannot desorb) and use an empirically derived function of $\mathrm{RH}$ and cuticle acidity to calculate a cuticle deposition velocity. This parameterization accounts for enhanced deposition to acidic water films on leaf surfaces. There are only a handful of field-scale $\mathrm{NH}_{3}$ models that allow for desorption of $\mathrm{NH}_{3}$ from drying water films on leaf cuticles (Burkhardt et al., 2009; Flechard et al., 1999; Neirynck and Ceulemans, 2008; Sutton et al., 1998). Three of these studies (Flechard et al., 1999; Neirynck and Ceulemans, 2008; Sutton et al., 1998) compared models with and without cuticle desorption and found that allowing for $\mathrm{NH}_{3}$ emission from water films on cuticles agrees better with observed fluxes during the morning. Other field-scale measurements attribute discrepancies between measured and modelled morning fluxes to $\mathrm{NH}_{3}$ emission during the drying of canopies (e.g. Bash et al., 2010; Walker et al., 2013; Wyers and Erisman, 1998). Most larger-scale (regional or global) chemical transport models (CTMs) still employ highly simplified deposition schemes for $\mathrm{NH}_{3}$ using look-up tables for deposition velocity and canopy resistance terms (Wesely, 1989). In other words, they treat deposition and emission of $\mathrm{NH}_{3}$ independently despite abundant field evidence that these processes are often highly coupled. However, some recent studies have successfully incorporated a bi-directional $\mathrm{NH}_{3}$ exchange framework into regional and global CTMs (Bash et al., 2013; Wichink Kruit et al., 2012; Zhu et al., 2015).

Although most $\mathrm{NH}_{3}$ surface-air exchange studies account for enhanced deposition to microscopic water films and several even model $\mathrm{NH}_{3}$ desorption, far fewer have attempted to assess the role that macroscopic dew has on influencing $\mathrm{NH}_{3}$ fluxes. This partly stems from the inherent difficulty in measuring dew amount, composition, and pH. Only a few $\mathrm{NH}_{3}$ surface-air exchange studies have attempted to measure dew composition and $\mathrm{pH}$, doing so by manually collecting enough individual droplets in pipettes to perform bulk analyses (Bash et al., 2010; Burkhardt et al., 2009; Walker et al., 2013). To constrain dew amount, Burkhardt et al. (2009) used an empirically derived relationship to approximate water film thickness from a leaf wetness sensor. Walker et al. (2013) estimated dew amount by difference in water mass between wet and dried leaves. Both studies acknowledge the large uncertainties associated with these methods for estimating total dew amount in the canopy. Regardless, Walker et al. (2013) estimated a maximum flux of $17.6 \mathrm{ng} \mathrm{NH}_{3} \mathrm{~m}^{-2} \mathrm{~s}^{-1}$ from dew evaporation in a fertilized corn canopy. One key assumption in this calculation is that all of the $\mathrm{NH}_{4}^{+}$present in dew is released as $\mathrm{NH}_{3}$ during evaporation.

Few studies have examined the fate of semi-volatile solutes (e.g. $\mathrm{NH}_{4}^{+} / \mathrm{NH}_{3}, \mathrm{NO}_{2}^{-} / \mathrm{HONO}$, acetate/acetic acid) in rain, cloud, fog, or dew during droplet evaporation. Takenaka et al. (2009) studied the chemistry of drying aqueous salts in a series of lab experiments and found that the fraction of "volatile" anions (which they operationally defined as $\mathrm{NO}_{2}^{-}$, acetate, and formate) remaining on the surface as a salt upon evaporation depends on the relative equivalents of "non-volatile" cations $\left(\mathrm{Na}^{+}, \mathrm{K}^{+}, \mathrm{Mg}^{2+}\right.$, and $\left.\mathrm{Ca}^{2+}\right)$ and "non-volatile" anions $\left(\mathrm{Cl}^{-}, \mathrm{NO}_{3}^{-}\right.$, and $\left.\mathrm{SO}_{4}^{2-}\right)$. The fraction of volatile anion $\left(X^{-}\right)$that is released during evaporation (as $\left.\mathrm{H} X_{(\mathrm{g})}\right)$ can then be predicted using the following equation (Takenaka et al., 2009):

$\operatorname{Frac}(X)=\frac{[X]_{i}-\left(\sum \text { cations }- \text { Lanions }\right)}{[X]_{i}}$, 
where $\operatorname{Frac}(X)$ is the fraction of the initial anion released to the atmosphere during evaporation, $[X]_{i}$ is the initial equivalents of "volatile" anion $X$, and $\Sigma$ cations and $\Sigma$ anions are the sums of "non-volatile" cations and anions respectively. The authors performed numerous experiments for $\mathrm{NO}_{2}^{-}$, acetate, and formate under a wide range of solute concentrations and $\mathrm{pH}$ values and found that Eq. (1) was consistently able to predict the fraction of each constituent liberated during evaporation of aqueous salt solutions. Although not the focus of the work, Takenaka et al. (2009) also performed some evaporation experiments on solutions containing $\mathrm{NH}_{4}^{+}$and were able to predict Frac $\left(\mathrm{NH}_{3}\right)$ with an analogous equation:

$\operatorname{Frac}\left(\mathrm{NH}_{3}\right)=\frac{\left[\mathrm{NH}_{4}^{+}\right]_{i}-(\Sigma \text { anions }-\Sigma \text { cations })}{\left[\mathrm{NH}_{4}^{+}\right]_{i}}$,

where $\left[\mathrm{NH}_{4}^{+}\right]_{i}$ is the initial ammonium concentration in the solution.

Few field studies have simultaneously quantified both dew and atmospheric composition. He et al. (2006) observed HONO emission from a drying forest canopy and performed lab studies to show that, on average, $\sim 90 \%$ of $\mathrm{NO}_{2}^{-}$was released as $\mathrm{HONO}$ during droplet evaporation. $\mathrm{Ru}-$ bio et al. $(2009,2012)$ found positive correlations between formaldehyde, phenols, and HONO in dew and the atmosphere. However, none of these studies, or those mentioned earlier for $\mathrm{NH}_{3}$, accurately measured dew amount (in $\mathrm{g} \mathrm{m}^{-2}$ ) on the surface, so the relative abundances of the analyte in the dew and gas phase could not be reliably calculated.

Therefore, great uncertainty exists regarding the influence of dew on boundary layer composition, particularly with respect to $\mathrm{NH}_{3}$ mixing ratios. Motivated by the paucity of data on dew-atmosphere $\mathrm{NH}_{3}$ fluxes, as well as uncertainties about the origin(s) of the frequently observed yet currently unexplained morning $\mathrm{NH}_{3}$ spike, the specific goals of this study are as follows:

- Determine the fate of $\mathrm{NH}_{4}^{+}$during dew evaporation (Sect. 3.1). What is the ratio of $\mathrm{NH}_{x}$ released as $\mathrm{NH}_{3}$ vs. $\mathrm{NH}_{4}^{+}$remaining on the surface as a non-volatile salt? What factor(s) govern this ratio?

- Simultaneously quantify dew amount, $\mathrm{NH}_{3}$ mixing ratio, and dew composition at the onset of evaporation at a field site (Sect. 3.2).

- Calculate the relative abundance of $\mathrm{NH}_{4}^{+}$in dew and $\mathrm{NH}_{3}$ in the boundary layer, as well as $\mathrm{NH}_{3}$ fluxes from dew evaporation (Sect. 3.3). Is dew a significant nighttime sink or reservoir for $\mathrm{NH}_{3}$ ? Is $\mathrm{NH}_{3}$ release from dew an important morning source?

- Evaluate whether $\mathrm{NH}_{3}$ is also released during rain evaporation (Sect. 3.4).

- Assess the impact of dew evaporation for other watersoluble gases (Sect. 3.5).

\section{Materials and methods}

\subsection{Drying chamber}

A drying chamber was used to determine the fraction of $\mathrm{NH}_{4}^{+}$ lost as $\mathrm{NH}_{3}$ during droplet evaporation and was based on the set-up used by Takenaka et al. (2009). The set-up consists of a zero air cylinder (AI Z300, AirGas) and mass flow controller which deliver zero air at a controlled flow rate into a drying chamber (URG-2000-30H, URG Corp.) containing droplets of synthetic dew. Downstream of the drying chamber is an annular denuder (URG-2000-30, URG Corp.) coated with a phosphorous acid solution $\left(10 \mathrm{~g} \mathrm{H}_{3} \mathrm{PO}_{3}\right.$ in $100 \mathrm{~mL}$ deionized water and $900 \mathrm{~mL} \mathrm{HPLC}$ grade methanol) to capture any $\mathrm{NH}_{3}$ emitted during dew drying.

At the beginning of each experiment, 26 droplets $(20 \mu \mathrm{L}$ each) of synthetic dew were deposited in the drying chamber and dried over the course of several hours by exposure to a flow of $2 \mathrm{~L} \mathrm{~min}^{-1}$ of zero air. Immediately after the last droplet had dried, the residue remaining in the chamber was extracted twice using two separate $10 \mathrm{~mL}$ aliquots of deionized water $\left(18.2 \mathrm{M} \Omega \mathrm{cm}^{-1}\right)$ and vigorous washing. The second aliquot always contained $<10 \%$ of each analyte relative to the first aliquot. The annular denuder was extracted by adding $10 \mathrm{~mL}$ of deionized water and rotating for $10 \mathrm{~min}$. Concentrations of ions in all three extracts were quantified using ion chromatography (IC) systems (DX-500, Dionex Inc.) and an isocratic elution scheme (1.8 / $1.7 \mathrm{mM} \mathrm{Na}_{2} \mathrm{CO}_{3} / \mathrm{NaHCO}_{3}$ solution for anions and $0.020 \mathrm{mM}$ methanesulfonic acid solution for cations). The $\mathrm{pH}$ of the dew was determined using a commercial $\mathrm{pH}$ metre (Orion Model 250A, Thermo Scientific). The fraction of each analyte remaining in the salt residue was then calculated, as well as the fraction of ammonium lost as $\mathrm{NH}_{3}$ based on the total $\mathrm{NH}_{x}$ amount measured in the three aliquots.

Experimental parameters (composition, $\mathrm{pH}$, and drying time) were varied to determine the factor(s) responsible for the fraction of $\mathrm{NH}_{3}$ that is released from dew as it dries. Synthetic dew was prepared by dissolving salts in deionized water to the desired concentration. All salts were reagent grade, obtained from Sigma Aldrich, and used without further purification. The $\mathrm{pH}$ was then adjusted with either concentrated acid $(\mathrm{HCl})$ or base $(\mathrm{NaOH})$. A total of nine different synthetic dew were prepared to mimic ambient dew composition reported from previous studies (e.g. Lekouch et al., 2010; Takenaka et al., 2003; Yadav and Kumar, 2014). The pH and concentrations of the nine synthetic dew are listed in Table S1 in the Supplement.

Synthetic dew was deposited as $20 \mu \mathrm{L}$ droplets, which corresponds to a hemispherical diameter of $\sim 4.25 \mathrm{~mm}$. Takeuchi et al. (2002) found that the diameter of most dew droplets range from 0.8 to $1.0 \mathrm{~mm}$ in diameter; however, applying such small droplets would bring the concentration of the extracts below detection limit. In order to maintain solute concentrations relevant to ambient dew, but generate 
sufficient signal for analysis, it was necessary to use $20 \mu \mathrm{L}$ droplets. The impact of larger droplet size on $\mathrm{NH}_{3}$ liberation was tested by performing several drying experiments on four $140 \mu \mathrm{L}$ drops ( $\sim 8.1 \mathrm{~mm}$ in diameter). These larger droplets had no effect on the fraction of $\mathrm{NH}_{3}$ emitted relative to the $20 \mu \mathrm{L}$ droplets.

\subsection{Field site}

Ambient measurements of dew composition, dew volume and gas-phase $\mathrm{NH}_{3}$ were obtained at a field site situated on the eastern edge of Rocky Mountain National Park (RMNP) in Northern Colorado $\left(40.2783^{\circ} \mathrm{N}, 105.5457^{\circ} \mathrm{W}\right.$; $2784 \mathrm{~m}$ a.s.l.) from $28 \mathrm{May}$ to 31 August 2015. The field site is remote with the nearest town (Estes Park, CO, population $\sim 6000$ ) located approximately $14 \mathrm{~km}$ north. This site is also used by the Interagency Monitoring of Protected Visual Environments (IMPROVE) and EPA Clean Air Status and Trends Network (CASTNet) programs for air quality monitoring and has been the location of extensive studies on nitrogen deposition (Beem et al., 2010; Benedict et al., 2013a) and atmospheric reactive nitrogen (Benedict et al., 2013b). The field site is a grassland clearing approximately $150 \mathrm{~m}$ in diameter surrounded by a mixed aspen and pine forest (average summertime maximum leaf area index of 1.5). In addition, excessive nitrogen deposition at RMNP has been linked to ecological impacts including changes in diatom assemblages (Baron, 2006; Wolfe et al., 2003) and shifts in a dry alpine meadow community (Bowman et al., 2012). Recently, Nanus et al. (2012) suggested that the critical load for nitrogen deposition (a value beyond which negative ecological impacts are observed) has been exceeded in $\sim 21 \%$ of the Rocky Mountains. The existing body of knowledge regarding reactive nitrogen at RMNP makes this site ideal to examine how dew-atmosphere interactions affect $\mathrm{NH}_{3}$ in the boundary layer as well as its deposition.

\subsection{Atmospheric measurements}

$\mathrm{NH}_{3}$ was measured using a Picarro G1103 Analzyer, a cavity ring-down spectroscopy instrument. The inlet line was $3.56 \mathrm{~cm}$ diameter Teflon tubing located approximately $2.5 \mathrm{~m}$ above ground level. The entire length of the $0.61 \mathrm{~m}$ inlet line was insulated and heated to $40^{\circ} \mathrm{C}$ to minimize wall losses. A filter (Picarro P/N S1021) was placed on the end of the inlet to prevent particles from entering the instrument. The filter was also heated, which may have caused $\mathrm{NH}_{4} \mathrm{NO}_{3}$ to volatilize from the filter or air stream, resulting in an overestimation of the ammonia concentration. However, a previous study at the site found that, on average, only a small fraction of particulate $\mathrm{NH}_{4}^{+}$exists as $\mathrm{NH}_{4} \mathrm{NO}_{3}$ during the summer (Benedict et al., 2013b). Furthermore, the same study found that $\mathrm{NH}_{3}$ was the majority of the $\mathrm{NH}_{x}\left(\equiv \mathrm{NH}_{3}+\mathrm{NH}_{4}^{+}\right)$loading. Hence, it is unlikely that there is a large interference from $\mathrm{NH}_{4} \mathrm{NO}_{3}$ volatilization.
Calibrations were performed twice during the field deployment using MKS mass flow controllers, a certified 2 ppm $\mathrm{NH}_{3}$ cylinder (AirGas), and a zero air source (Teledyne Zero Air Generator Model 701). The calibration gas was split between the Picarro and a phosphorous acid $(10 \% \mathrm{w} / \mathrm{v})$ coated denuder to act as a check of the concentration. The denuder was sampled at $2 \mathrm{~L} \mathrm{~min}^{-1}$ and the total volume was recorded using a dry gas metre. The concentration determined by the denuder was used as the "true" concentration in the calibration curve.

Meteorological measurements were made at the site by a $10 \mathrm{~m}$ tower operated by the National Park Service. Measurements are reported at $1 \mathrm{~h}$ intervals for solar radiation, temperature, wind speed, wind direction, standard deviation of the wind direction over the period, relative humidity, and rainfall.

\subsection{Dew measurements}

Ambient dew samples at RMNP were gathered using a dew collector with a design similar to Guan et al. (2014). The collector was built in-house and consists of a wooden base that supports a $7 \mathrm{~cm}$ thick polystyrene foam block with an area of $48 \times 60 \mathrm{~cm}$. The top surface of the polystyrene block is covered by a $0.2 \mathrm{~mm}$ thick polytetrafluoroethylene (Teflon ${ }^{\circledR}$ ) sheet. The Teflon ${ }^{\circledR}$ sheet is parallel to the ground at a height of $30 \mathrm{~cm}$. During the night the Teflon ${ }^{\circledR}$ sheet undergoes radiative cooling while the polystyrene insulates the sheet from below. This results in dew formation on the Teflon ${ }^{\circledR}$ surface which can be manually collected into clean sample bottles the following morning using a pre-cleaned scraper and funnel. The emissivity of Teflon ${ }^{\circledR}$ is 0.94 (Baldridge et al., 2009) and is very similar to that of vegetation (0.95) (Guan et al., 2014).

The dew collector was deployed before dusk on nights that had a forecast favourable for dew formation (high relative humidity, light winds, and clear skies). The Teflon ${ }^{\circledR}$ surface was cleaned immediately before deployment in a two-step process: (1) splashing $\sim 1 \mathrm{~L}$ of deionized water across the surface, followed by (2) squirting $\sim 30 \mathrm{~mL}$ of deionized water on the surface and scraping it off using a plastic scraper. The latter step was repeated 10 times, and the tenth rinse was collected and used as a field blank for dew collected the following morning. Prior to dew collection, the funnel and scraper were rinsed 10 times with deionized water. This cleaning procedure proved sufficient and is similar to prior studies using a similar collector (e.g. Okochi et al., 2008; Wagner et al., 1992). Dew samples were collected into $15 \mathrm{~mL}$ polypropylene sample bottles in order to minimize headspace during transport and storage.

When rain had occurred during the night, then rain samples were also collected off of the dew collector in a similar fashion the following morning. Rain samples were unambiguously identified using data from the dewmeter described below. 
Chemical analyses of all dew samples were performed within $6 \mathrm{~h}$ of collection, with the exception of one sample which was stored at $4{ }^{\circ} \mathrm{C}$ and analysed $48 \mathrm{~h}$ later. The concentration of ions $\left(\mathrm{Na}^{+}, \mathrm{NH}_{4}^{+}, \mathrm{K}^{+}, \mathrm{Mg}^{2+}, \mathrm{Ca}^{2+}, \mathrm{Cl}^{-}, \mathrm{NO}_{2}^{-}\right.$, $\mathrm{NO}_{3}^{-}, \mathrm{SO}_{4}^{2-}, \mathrm{PO}_{4}^{3-}$, acetate, formate, and oxalate) in dew samples was determined through ion chromatography and $\mathrm{pH}$ was measured with a $\mathrm{pH}$ metre, as outlined in Sect. 2.1. The total organic carbon (TOC) and inorganic carbon (IC) were quantified with a commercial TOC analyser (TOC$V_{\mathrm{CSH}}$, Shimadzu Corp.) equipped with a total nitrogen (TN) analyser (TNM-1, Shimadzu Corp.) for quantification of TN. Concentrations of analytes in ambient dew samples were background corrected by subtracting the volume-weighted concentration in the tenth rinse collected the prior evening, which is likely an upper bound for the background signal given that some volatile solutes will be scavenged from the air during application and collection of the rinse.

It was also necessary to quantify the volume of dew $\left(V_{\text {dew }}\right)$ that formed each night. The dew collector is not suitable since $V_{\text {dew }}$ obtained from the collector is not necessarily representative of $V_{\text {dew }}$ that forms naturally on the grassland canopy at RMNP. Numerous methods and instruments exist to measure $V_{\text {dew }}$; for instance, the cloth-plate method (Ye et al., 2007), lysimeter-related instruments (Grimmond et al., 1992; Price and Clark, 2014), and eddy-correlation techniques (Moro et al., 2007). Although there is no standard method to measure $V_{\text {dew }}$, Richards (2004) provides a detailed overview of various techniques that have been used to collect and quantify dew.

For this study, we constructed a dewmeter similar to that of Price and Clark (2014). The design consists of a circular collection tray (diameter of $35 \mathrm{~cm}$ ) that is attached to the top of an analytical balance (HRB 3002, LWC Measurements). The balance has a resolution of $0.01 \mathrm{~g}$ and a maximum load of $3000 \mathrm{~g}$. The tray contains artificial turf that is intended to be representative of the grass at the RMNP field site during the early part of the growing season. The balance was contained in a weatherproof box with a hole cut in the lid to accommodate the tray/turf. The mass on top of the balance was recorded to a laptop at a rate of $5 \mathrm{~Hz}$ so that the mass of dew was continuously monitored as it formed and evaporated. The data were averaged to $10 \mathrm{~min}$ to achieve better signal-to-noise ratio.

Price and Clark (2014) performed an extensive characterization of the dewmeter and compared dew formation/evaporation on co-located dewmeters containing real turf and artificial turf. The authors found that $V_{\text {dew }}$ and the dew deposition rate were identical between the two turfs. In other words, the radiative properties and surface area of artificial turf sufficiently mimic real turf such that artificial turf can be used as a surrogate to quantify $V_{\text {dew }}$ and its temporal evolution. The advantage of using artificial turf is that there are no changes in mass due to evapotranspiration during the daytime. The dewmeter is also capable of quantifying rain- fall and its evaporation. However, if the rainfall is too intense $(\geq 2 \mathrm{~mm}$ ) then the tray becomes flooded and must be replaced with a dry tray/turf.

\subsection{Flux calculation}

$\mathrm{NH}_{3}$ fluxes from dew evaporation were calculated using the following equation:

$F_{\mathrm{NH}_{3}}=\frac{\left[\mathrm{NH}_{4}^{+}\right] \cdot V_{\text {dew }}}{t_{\text {evap }}} \cdot \operatorname{Frac}\left(\mathrm{NH}_{3}\right) \cdot 17031$,

where $F_{\mathrm{NH}_{3}}$ is the average emission flux (in $\mathrm{n} \mathrm{m}^{-2} \mathrm{~s}^{-1}$ ) during dew drying, $\left[\mathrm{NH}_{4}^{+}\right]$is the concentration of ammonium in dew (in $\mu \mathrm{M}$ ), $V_{\text {dew }}$ is the volume of dew in the canopy (in $\mathrm{L} \mathrm{m}^{-2}$ ), $t_{\text {evap }}$ is the time it takes for dew to evaporate (in s), $\operatorname{Frac}\left(\mathrm{NH}_{3}\right)$ is the fraction of $\mathrm{NH}_{4}^{+}$in the dew that is released as $\mathrm{NH}_{3}$, and 17031 is to convert $\mu \mathrm{mol}$ to $\mathrm{ng}$. It is important to note that Eq. (3) yields the average $F_{\mathrm{NH}_{3}}$ during evaporation and cannot account for any variations in $F_{\mathrm{NH}_{3}}$ over the evaporation period. The dewmeter was used to record $V_{\text {dew }}$ and $t_{\text {evap }}$, whereas sample from the dew collector was used to quantify $\left[\mathrm{NH}_{4}^{+}\right]$and calculate $\operatorname{Frac}\left(\mathrm{NH}_{3}\right)$. The dewmeter is automated and was deployed continuously from 22 June until 31 August (and intermittently between 27 May and 21 June), whereas the dew collector requires manual cleaning and collection and so was only deployed when forecasts were favourable for dew formation.

\section{Results and discussion}

\subsection{Fraction of $\mathrm{NH}_{3}$ that evaporates from drying dew}

We tested the validity of Eq. (2) by performing a series of drying experiments similar to Takenaka et al. (2009) but specifically targeting conditions relevant for dew (i.e. composition and drying time). Takenaka et al. (2009) used solutions in the mM range with drying times of $\sim 9 \mathrm{~h}$, whereas natural dew is typically less concentrated ( $\mu \mathrm{M}$ range) and usually dries within a few hours. The composition of synthetic dew (Table S1 in the Supplement) and drying time $(\sim 2.5 \mathrm{~h})$ in this work is a better representation of natural dew.

Figure 1 shows the measured $\operatorname{Frac}\left(\mathrm{NH}_{3}\right)$ vs. predicted Frac $\left(\mathrm{NH}_{3}\right)$ from an updated form of Eq. (2) (see below for details) for the nine synthetic dew. Drying experiments were performed three times per dew composition, and error bars in Fig. 1 denote the standard deviation between experiments. The amount of $\mathrm{NH}_{x}\left(\equiv \mathrm{NH}_{4}^{+}+\mathrm{NH}_{3}\right)$ recovered was always within $20 \%$ of the amount of $\mathrm{NH}_{4}^{+}$added at the beginning of the experiment. There is good agreement between the measured and predicted Frac $\left(\mathrm{NH}_{3}\right)$, which is mostly consistent with the findings of Takenaka et al. (2009) with a few key differences: (1) the majority of acetate and formate remained as a salt after evaporation, (2) $\mathrm{HCO}_{3}^{-}$was an important constituent in the anion balance, and (3) the pKa of each substance must be considered. Although acetic acid, formic acid, 


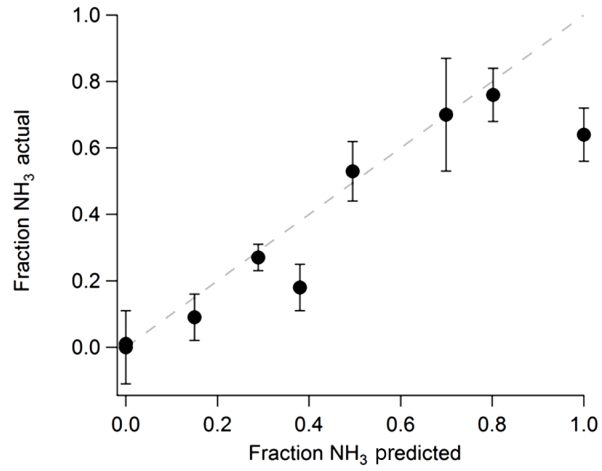

Figure 1. Fraction of $\mathrm{NH}_{3}$ liberated during drying experiments vs. the fraction predicted according to an updated Eq. (2) to include acetate, formate, $\mathrm{CO}_{3}^{2-}$, and $\mathrm{HCO}_{3}^{-}$in the anion balance. Excluding these anions significantly reduces the correlation. Error bars represent $\pm \sigma$ from three experiments per synthetic dew. The dashed line is the $1: 1$ line.

and carbonic acid are relatively volatile, the conjugate bases can (and do) form non-volatile salts upon evaporation when there is an excess of cations. Furthermore, if the $\mathrm{pH}$ is near or less than the $\mathrm{pKa}$ of the acids then a significant fraction will be neutral (protonated) and unable to form a salt. Hence, we update the definition of $\Sigma$ anions in Eq. (2) to include acetate, formate, and bicarbonate (also reflected in Fig. 1), which yield much better agreement in predicted vs. measured $\operatorname{Frac}\left(\mathrm{NH}_{3}\right)$.

Since ion chromatography quantifies the total amount of each species (i.e. both charged and neutral forms) it is necessary to use $\mathrm{pH}$ and the acid dissociation constant $\left(K_{\mathrm{a}}\right)$ for each species to calculate the ionic fraction of each. Furthermore, Takenaka et al. (2009) recommend including carbonate/bicarbonate in the ion balance for field samples. The authors did not account for $\mathrm{CO}_{2}$ equilibria since their lab experiments were performed under strict $\mathrm{CO}_{2}$-free conditions, whereas our synthetic dew samples had sufficient exposure to lab air to equilibrate with atmospheric $\mathrm{CO}_{2}(\sim 500 \mathrm{ppm}$ in the lab) as verified by subsequent inorganic carbon measurements (Sect. 2.4). Hence, we calculated the amount of $\mathrm{HCO}_{3}^{-}$ and $\mathrm{CO}_{3}^{2-}$ in synthetic dew using $\mathrm{pH}$ and carbonate equilibria assuming $P_{\mathrm{CO}_{2}}=500 \mathrm{ppm}$. Charge imbalance calculated in Eq. (2) is a result of $\mathrm{CO}_{2}$ dissolving (or outgassing when a large quantity of bicarbonate/carbonate salt was added) as well as the addition of $\mathrm{HCl}$ or $\mathrm{NaOH}$.

\subsection{Dew parameters}

A total of 12 dew samples for chemical analysis were collected at RMNP over the study period. The equivalent concentrations of ions are given in Fig. 2 and TOC, IC, TN, $\mathrm{pH}$, and $\mathrm{Frac}\left(\mathrm{NH}_{3}\right)$ in Table 1. Average values of $\left[\mathrm{NH}_{4}^{+}\right]$ in dew found in the literature span several orders of magnitude ranging from $25 \mu \mathrm{M}$ in coastal Croatia (Lekouch et al.,

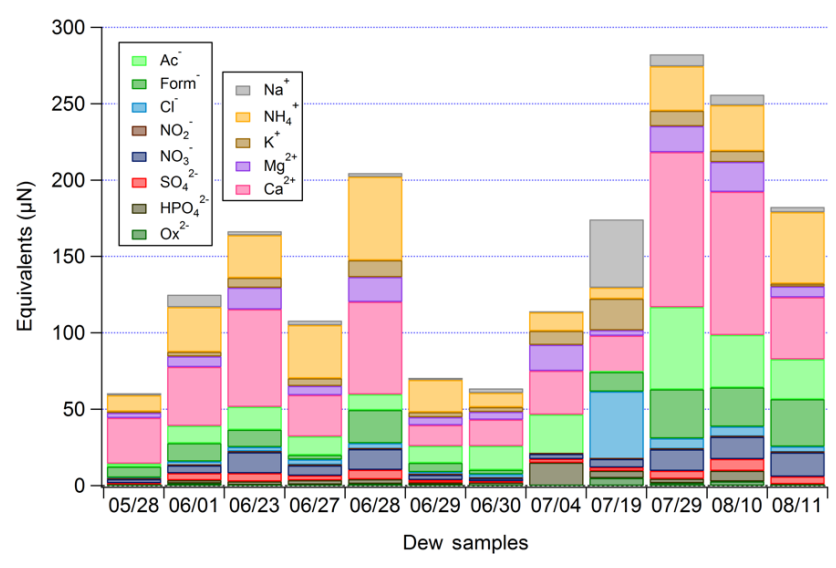

Figure 2. Ionic composition (in $\mu \mathrm{N}$ ) of ambient dew collected at RMNP.

2010) to $1600 \mu \mathrm{M}$ in urban India (Yadav and Kumar, 2014). Dew at RMNP is at the lower end of this range with median $\left[\mathrm{NH}_{4}^{+}\right]=28 \mu \mathrm{M}$. In general, the concentrations of all species in RMNP dew are lower than most previous studies (e.g. Singh et al., 2006; Takenaka et al., 2003; Wagner et al., 1992). This is due to the remoteness of RMNP resulting in low levels of coarse mode aerosol and water-soluble gases which tend to control the composition of dew via deposition and dissolution (Takeuchi, 2003; Wagner et al., 1992). The dominant cations in dew at RMNP are $\mathrm{Ca}^{2+}$ and $\mathrm{NH}_{4}^{+}$. The former is likely from the deposition of coarse mode soil and/or dust particles and the latter from gas-phase dissolution of $\mathrm{NH}_{3}$. Acetate and formate are the major anions and may be the result of dissolution of acetic and formic acid (Wagner et al., 1992) and/or the products of aqueous-phase oxidation of semi-volatile organics (SVOCs, e.g. aldehydes) which has been observed in cloud and fog water (Herckes et al., 2007, 2013; Munger et al., 1989). The area surrounding the field site is heavily forested and the boundary layer is likely rich in biogenic SVOCs, which could explain the high TOC content in the dew (average $=6.23 \mathrm{mg} \mathrm{C} \mathrm{L}^{-1}$ ). The ability for dew to act as a medium for aqueous-phase oxidation of SVOCs is outside the scope of this paper but warrants further investigation.

The average $\mathrm{pH}$ of dew at RMNP was 5.19 (median $=5.34$ ), which is on the lower range of what has been reported for dew. For instance, Yaalon and Ganor (1968) and $\mathrm{Xu}$ et al. (2015) found median dew pH of 7.7 and 6.72 in Jerusalem and Changchun, China, respectively, whereas Pierson et al. (1986) reported an average dew pH of 4.0 at a rural site in Pennsylvania in a region containing several coalfired power plants. Given the remoteness of RMNP and low ionic concentrations, $\mathrm{CO}_{2}$ dissolution plays an important role in governing dew $\mathrm{pH}$. Acidic dew are considered to enhance deposition of $\mathrm{NH}_{3}$ and hinder that of certain weakly acidic gases (e.g. $\mathrm{SO}_{2}$, organic acids) (Chameides, 1987; Okochi et al., 1996). In addition, the average summertime $\mathrm{NH}_{3}$ mixing 
Table 1. Total organic carbon (TOC), total nitrogen (TN), inorganic carbon (IC), $\mathrm{pH}$, the ratio of measured to predicted [NH $\left.{ }_{4}^{+}\right]$in dew, and parameters pertinent to $\mathrm{NH}_{3}$ flux calculations in the field dew samples.

\begin{tabular}{|c|c|c|c|c|c|c|c|c|c|}
\hline Date & $\begin{array}{r}\text { TOC } \\
\left(\mathrm{mg} \mathrm{CL}^{-1}\right)\end{array}$ & $\begin{array}{r}\mathrm{IC} \\
\left(\mathrm{mg} \mathrm{CL}^{-1}\right)\end{array}$ & $\begin{array}{r}\mathrm{TN} \\
\left(\mathrm{mg} \mathrm{NL}^{-1}\right)\end{array}$ & $\mathrm{pH}$ & $\operatorname{Frac}\left(\mathrm{NH}_{3}\right)$ & $\begin{array}{r}V_{\mathrm{dew}} \\
\left(\mathrm{mL} \mathrm{m}^{-2}\right)\end{array}$ & $\begin{array}{r}t_{\text {evap }} \\
(\mathrm{s})\end{array}$ & $\begin{array}{r}\text { Flux } \\
\left(\mathrm{ng} \mathrm{m}^{-2} \mathrm{~s}^{-1}\right)\end{array}$ & {$\left[\mathrm{NH}_{4}^{+}\right]_{\text {meas }}:\left[\mathrm{NH}_{4}^{+}\right]_{\text {eqm }}$} \\
\hline 28 May & 0.65 & 0.52 & 0.05 & 5.46 & 1.0 & 79.8 & 6000 & 2.4 & 0.02 \\
\hline 1 Jun & 2.05 & 1.21 & 0.32 & 5.65 & 0.68 & 97.0 & 6600 & 4.9 & 0.08 \\
\hline 23 Jun & 6.10 & 0.58 & 0.61 & 5.35 & 1.0 & 167.2 & 10800 & 7.3 & 0.02 \\
\hline 27 Jun & 6.13 & 0.59 & 0.62 & 5.70 & 0.85 & 195.6 & 9000 & 11.0 & 0.05 \\
\hline 28 Jun & 9.69 & 0.56 & 0.95 & 5.16 & 1.0 & 161.6 & 8400 & 17.9 & 0.04 \\
\hline 29 Jun & 5.27 & 0.19 & 0.46 & 4.83 & 1.0 & 60.9 & 3000 & 7.3 & 0.01 \\
\hline 30 Jun & 6.71 & 0.22 & 0.32 & 4.99 & 1.0 & 163.4 & 7800 & 3.3 & 0.01 \\
\hline $4 \mathrm{Jul}$ & 6.78 & 0.23 & 1.40 & 5.32 & 1.0 & 206.8 & 16800 & 2.5 & 0.02 \\
\hline $19 \mathrm{Jul}$ & 6.53 & 0.11 & 1.47 & 5.85 & 1.0 & 188.2 & 24600 & 1.0 & 0.08 \\
\hline $29 \mathrm{Jul}$ & 10.04 & 0.31 & 2.59 & 5.80 & 1.0 & 92.2 & 8400 & 5.4 & 0.09 \\
\hline 10 Aug & 7.54 & 0.38 & 0.80 & 5.34 & 1.0 & 96.9 & 7200 & 6.9 & 0.07 \\
\hline 11 Aug & 7.28 & 0.17 & 0.85 & 4.67 & 0.74 & 108.4 & 14400 & 4.2 & 0.02 \\
\hline Avg & 6.23 & 0.42 & 0.85 & 5.19 & 0.94 & 134.8 & 10250 & 6.2 & 0.04 \\
\hline
\end{tabular}

ratio at RMNP is about a factor of 3 higher than that of $\mathrm{HNO}_{3}$ (Benedict et al., 2013b), which is roughly the same ratio as $\mathrm{NH}_{4}^{+}: \mathrm{NO}_{3}^{-}$in dew measured in this study.

Figure 2 reveals a persistent ion imbalance for ambient dew samples. On average, about $25 \%$ more anion is needed to achieve ion balance with the measured cations. This implies that some anions are unaccounted for in the system. Possible explanations include (1) longer chain organic acids (e.g. succinate, maleate, malonate, and pyruvate) and/or (2) silicates from wind-blown dust.

Equation (2) was used to calculate Frac $\left(\mathrm{NH}_{3}\right)$ for ambient dew samples (average $=0.94$ ). Only 3 of the 12 samples had a $\operatorname{Frac}\left(\mathrm{NH}_{3}\right)$ less than 1 meaning that, in most cases, all of the $\mathrm{NH}_{4}^{+}$present is predicted to volatilize as $\mathrm{NH}_{3}$ during dew evaporation. It is important to note that acetate, formate, and $\mathrm{HCO}_{3}^{-}$were included in the $\sum$ anion budget in contrast to Takenaka et al. (2009). Had the aforementioned anions not been included in the $\operatorname{Frac}\left(\mathrm{NH}_{3}\right)$ calculation then all dew samples would have Frac $\left(\mathrm{NH}_{3}\right)=1$.

The high Frac $\left(\mathrm{NH}_{3}\right)$ has an important implication for $\mathrm{N}$ deposition: $\mathrm{NH}_{3}$ that is dry deposited onto a surface wetted with dew does not necessarily contribute to $\mathrm{N}$ deposition. In other words, $\mathrm{NH}_{3}$ deposited into dew overnight should not necessarily be counted towards the total $\mathrm{N}$-deposition budget for a given ecosystem. The consequence of this implication likely extends beyond RMNP and merits additional field measurements of dew to calculate $\operatorname{Frac}\left(\mathrm{NH}_{3}\right)$ in other environments (e.g. agricultural, urban, and rural). To our knowledge, this is the first field study to quantify the extent to which $\mathrm{NH}_{4}^{+}$is released as $\mathrm{NH}_{3}$ during dew evaporation. Additional research is needed to examine the effects of (1) salts already present on vegetative surfaces on dew composition, (2) dew transfer from leaf to soil prior to evaporation, and (3) different canopies (e.g. forest, tall grass) on the amount and timing of dew accumulation and evaporation.

\subsection{Dew-atmosphere $\mathrm{NH}_{3}$ fluxes}

In this section we examine how the formation and evaporation of dew impacts $\mathrm{NH}_{3}$ in the boundary layer. Figure 3 shows time series (from 19:00 to 11:00 the following day) of dew mass $\left(\mathrm{g} \mathrm{m}^{-2}\right)$, air temperature $\left({ }^{\circ} \mathrm{C}\right)$, and $\mathrm{NH}_{3}$ mixing ratio (ppbv) on four separate nights with dew. One feature common to all four panels is the increase of $\mathrm{NH}_{3}$ at the onset of dew evaporation followed by a plateau or decrease of $\mathrm{NH}_{3}$ once the surface had dried completely. The features in Fig. 3 are representative of the other 29 nights in which dew formed during the study period (27 May to 31 August). It should be noted that in Fig. 3c and d the start of the morning $\mathrm{NH}_{3}$ increase is slightly delayed from the onset of dew evaporation. This may be attributed to canopy growth over the course of the campaign - during May and June (Fig. 3a and b) the grassland canopy was relatively short $(\sim 5 \mathrm{~cm})$ and roughly the same height as the artificial turf on the dewmeter. However, during July (Fig. 3c) and August (Fig. 3d) the canopy had grown significantly (up to $\sim 30 \mathrm{~cm}$ ), providing significant shade to lower parts of the grass such that dew finished evaporating off the dewmeter prior to complete drying of the canopy. This would also cause an underestimation of dew amount by the dewmeter towards the end of the measurement period.

The consistent timing between dew evaporation and the increase in $\mathrm{NH}_{3}$ mixing ratio is strong evidence that dew evaporation and the early morning $\mathrm{NH}_{3}$ increases are linked, but other phenomena must be considered. For instance, it is well known that $\mathrm{NH}_{3}$ emissions from plant stomata and soil are heavily temperature dependent and increase at higher temperatures (Massad et al., 2010; Sutton et al., 2013; Zhang et al., 2010). However, $\mathrm{NH}_{3}$ decreases after dew evaporation ceases despite a continued increase in temperature, suggesting that this morning increase is not from stomata or 


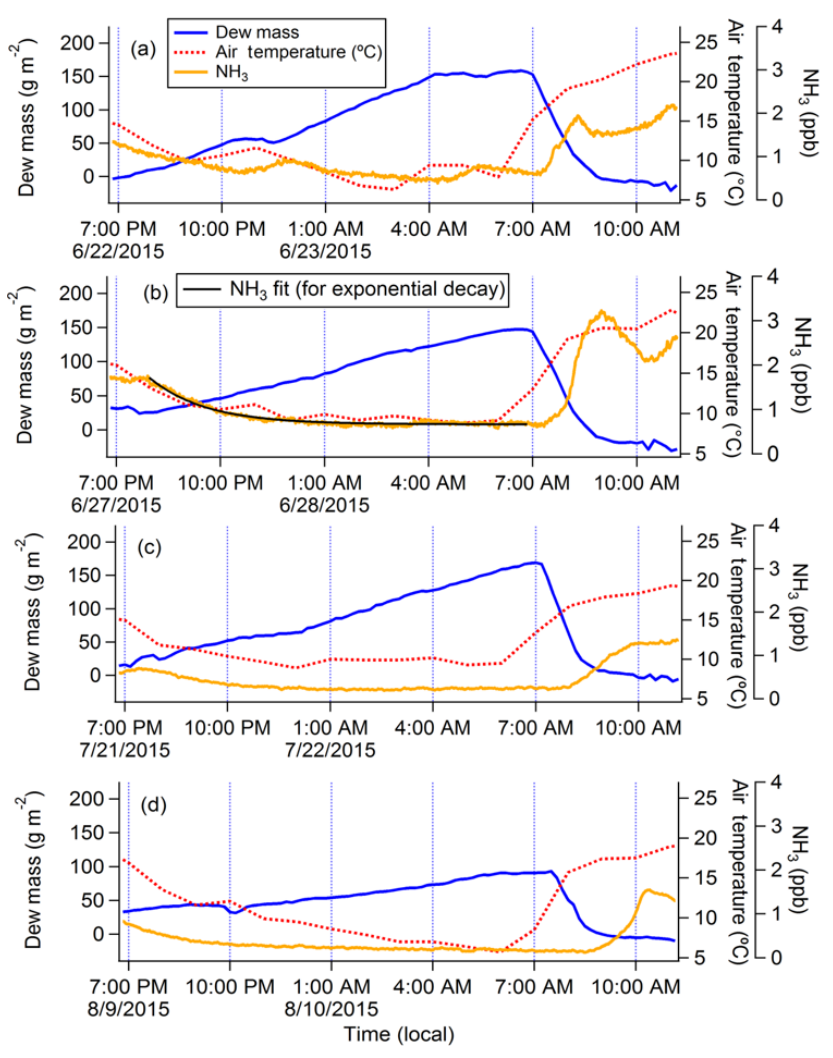

Figure 3. Dew accumulation (blue, $\mathrm{g} \mathrm{m}^{-2}$ ), $\mathrm{NH}_{3}$ mixing ratio (orange, ppbv), and air temperature (red, ${ }^{\circ} \mathrm{C}$ ) overnight on (a) 22 June, (b) 27 June, (c) 21 July, and (d) 9 August 2015. The black line in (b) is the best fit for the $\mathrm{NH}_{3}$ mixing ratio to an exponential decay function (see Eq. 4) between 20:00 and the onset of dew evaporation.

soil emissions. Another possible explanation is reduced deposition after dew evaporation since wet canopies provide a lower resistance to deposition for water-soluble gases (e.g. $\mathrm{NH}_{3}$ ) relative to dry canopies (Fowler et al., 2009; Neirynck and Ceulemans, 2008); however, this scenario requires other continuous source(s) of $\mathrm{NH}_{3}$. If this were the mechanism responsible for morning $\mathrm{NH}_{3}$ increases then one would expect a plateau in $\mathrm{NH}_{3}$ after canopy drying. However, Fig. 3a, b, and d all show $\mathrm{NH}_{3}$ decreases after dew evaporation. In addition, RMNP is sufficiently remote that morning $\mathrm{NH}_{3}$ increases cannot be from rush-hour traffic or industrial sources.

It is also useful to consider the behaviour of $\mathrm{NH}_{3}$ on mornings without dew. Of the 72 nights during which the dewmeter was deployed and functioning, there was night-time rain on 23 of the nights and no surface wetness (neither rain nor dew) at sunrise on 16 nights. Typically, dew formation began around 20:30 and it had completely evaporated by 09:00 the following morning. Figure 4 compares $\mathrm{NH}_{3}$ mixing ratios from 04:00 to 11:00 on mornings with dew (Fig. 4a) and without dew or rain (Fig $4 b$ ). The clear morning $\mathrm{NH}_{3}$ increase only happens on mornings with dew, further sup-

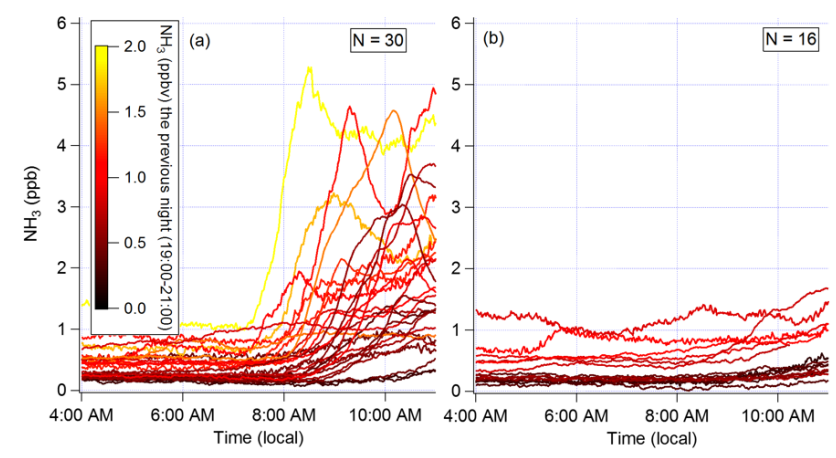

Figure 4. Time series of $\mathrm{NH}_{3}$ mixing ratio (in ppb) from 04:00 to 11:00 on (a) mornings with dew and (b) mornings with no surface wetness. Traces are coloured according to the average $\mathrm{NH}_{3}$ mixing ratio measured the previous night between 19:00 and 21:00.

porting the hypothesis that dew evaporation has a significant influence on near-surface $\mathrm{NH}_{3}$ mixing ratios. The traces in Fig. 4 are coloured according to the average $\mathrm{NH}_{3}$ mixing ratio the previous night (from 19:00 to 21:00). The magnitude of the morning increase is related to the amount of $\mathrm{NH}_{3}$ present the previous night suggesting that most of the $\mathrm{NH}_{4}^{+}$ in dew is a result of $\mathrm{NH}_{3}$ dissolution. This is additional evidence that $\mathrm{NH}_{3}$ deposited in dew overnight at RMNP is recycled back to the atmosphere the following morning upon evaporation and should not be counted towards total $\mathrm{N}$ deposition. In other words, the dew acts as a temporary reservoir for atmospheric ammonia and the cycle of dew formation and evaporation has a strong influence on boundary layer $\mathrm{NH}_{3}$ concentrations.

Table 1 shows the calculated $\mathrm{NH}_{3}$ fluxes from dew during evaporation (average $=6.2 \mathrm{ng} \mathrm{m}^{-2} \mathrm{~s}^{-1}$ ) as well as the relevant parameters required for flux calculations ( $t_{\text {evap}}$, Frac $\left(\mathrm{NH}_{3}\right)$, and $\left.V_{\text {dew }}\right)$. To our knowledge, only two studies to date have reported $\mathrm{NH}_{3}$ fluxes in a non-fertilized grassland. Wichink Kruit et al. (2007) used the aerodynamic gradient method to measure a daily average summertime $\mathrm{NH}_{3}$ flux of $4 \mathrm{ng} \mathrm{m}^{-2} \mathrm{~s}^{-1}$ in a field in the Netherlands, whereas Wentworth et al. (2014) inferred a daily average soil emission flux of $2.6 \mathrm{ng} \mathrm{m}^{2} \mathrm{~s}^{-1}$ during August in a rural field near Toronto, Canada, using simultaneous soil and atmospheric measurements and a simple resistance model. In the context of these previous studies over the same land type, the dewrelated $\mathrm{NH}_{3}$ fluxes at RMNP are significant. Furthermore, it is likely that dew-related $\mathrm{NH}_{3}$ fluxes would be substantially larger at the other field sites given that $\mathrm{NH}_{3}$ mixing ratios were a factor of 3-10 higher which would result in higher dew $\left[\mathrm{NH}_{4}^{+}\right]$.

It is likely that during some periods the emission/deposition footprint of the atmospheric and dew measurements extends beyond the grassland clearing and into the surrounding forest. While we did not find that the overnight loss rate of ammonia depended on dew amount, the deposi- 
tion rate of ammonia likely depends on surface type, so estimates of moles of $\mathrm{NH}_{3}$ deposited per $\mathrm{m}^{2}$ from the dew collector may not be representative of the surrounding forest. Upslope and downslope flow conditions could also explain some of the variability in nocturnal $\mathrm{NH}_{3}$ since the latter is prevalent during the night-time and delivers cleaner air from the west of RMNP. Subsequent work should be performed to examine the representativeness of grassland dew measurements to the larger surrounding ecosystem.

For the 12 dew samples listed in Table 1, a simple calculation was performed to estimate the moles of $\mathrm{NH}_{4}^{+}$contained in dew relative to the moles of $\mathrm{NH}_{3}$ in the boundary layer. Particulate $\mathrm{NH}_{4}^{+}$is not considered due to its low mass loadings at RMNP (Benedict et al., 2013b). The $\mu \mathrm{mol} \mathrm{m}{ }^{-2}$ of $\mathrm{NH}_{4}^{+}$in dew at the onset of evaporation was calculated by multiplying $V_{\text {dew }}$ by dew $\left[\mathrm{NH}_{4}^{+}\right]$. One inherent assumption is that $\left[\mathrm{NH}_{4}^{+}\right]_{\text {dew }}$ on the collector is representative of the dew on the dewmeter. An equivalent mole loading (also in $\mu \mathrm{mol} \mathrm{m}{ }^{-2}$ ) of $\mathrm{NH}_{3}$ in the boundary layer was calculated by first converting the measured mixing ratio from ppbv to $\mu \mathrm{mol} \mathrm{m}{ }^{-3}$ and then multiplying by an assumed boundary layer depth of $150 \mathrm{~m}$. The average ratio of $\mathrm{NH}_{4, \text { dew }}^{+}: \mathrm{NH}_{3, \mathrm{BL}}$ is $1.6 \pm 0.7$ for the 12 dew samples collected. In other words, on a per mole basis there is nearly double the $\mathrm{NH}_{4}^{+}$in dew than there is $\mathrm{NH}_{3}$ in a $150 \mathrm{~m}$ deep boundary layer. Unfortunately, there are no measurements at RMNP that allow a better constraint of the boundary layer height. Assuming a smaller (larger) boundary layer height would increase (decrease) the $\mathrm{NH}_{4, \text { dew }}^{+}: \mathrm{NH}_{3, \mathrm{BL}}$ ratio.

The measured loss of $\mathrm{NH}_{3}$ (in ppbv) during dew nights was used to estimate the sink of $\mathrm{NH}_{3}$ (in $\mu \mathrm{mol} \mathrm{m}^{-2}$ ) between the onset of dew formation and evaporation. This loss was estimated in a similar fashion as above, assuming (1) $150 \mathrm{~m}$ nocturnal boundary layer, (2) no reactive sinks (e.g. $\mathrm{NH}_{4} \mathrm{NO}_{3}$ formation), (3) no exchange with the free troposphere, and (4) no influence from horizontal advection (i.e. upslope/downslope flow) on $\mathrm{NH}_{3}$. Figure 5 shows a correlation plot of estimated $\mathrm{NH}_{3}$ lost on dew nights vs. the observed $\mathrm{NH}_{4}^{+}$accumulated in dew. The good correlation and near-unity slope (0.71) show that there is approximate mass closure between $\mathrm{NH}_{3}$ lost overnight and $\mathrm{NH}_{3}$ sequestered by dew. Although these calculations are simplistic it is evident that, on average, dew sequesters a significant portion (estimated at nearly two-thirds) of $\mathrm{NH}_{3}$ over the course of the night. Subsequent studies on dew-atmosphere interactions should include measurements of boundary layer height so a more thorough mass balance calculation can be performed.

The loss rate of $\mathrm{NH}_{3}$ on dew nights vs. dry nights was examined by fitting the $\mathrm{NH}_{3}$ mixing ratio to an exponential decay function between 20:00 and 09:00 (or dew evaporation) on the 46 nights in Fig. 4. The fit function used was

$\left[\mathrm{NH}_{3}\right]_{t}=\left[\mathrm{NH}_{3}\right]_{\text {sunset }} e^{-k t}+\left[\mathrm{NH}_{3}\right]_{\text {overnight }}$,

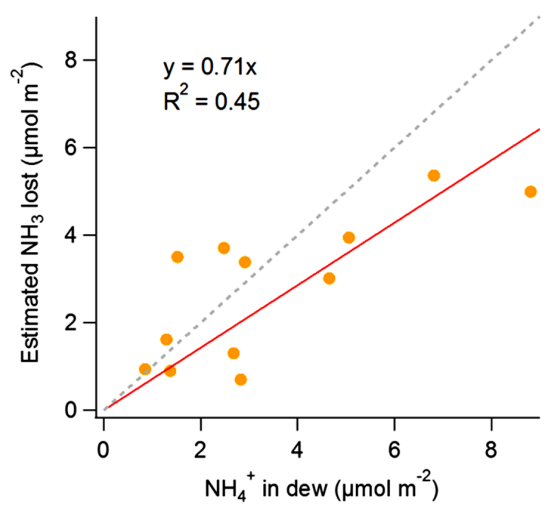

Figure 5. Estimated $\mathrm{NH}_{3}$ lost overnight assuming a $150 \mathrm{~m}$ boundary layer vs. measured $\mathrm{NH}_{4}^{+}$accumulated in dew by the onset of evaporation. The red line is the best fit line (forced through the origin) and the dashed grey line is the $1: 1$ line.

where $\left[\mathrm{NH}_{3}\right]_{t}$ is the mixing ratio of $\mathrm{NH}_{3}$ at time $t$, $\left[\mathrm{NH}_{3}\right]_{\text {sunset }}$ is the mixing ratio at $20: 00,\left[\mathrm{NH}_{3}\right]_{\text {overnight }}$ is the plateau in nocturnal $\mathrm{NH}_{3}$ mixing ratio, and $k$ is an empirical fit parameter representing the apparent first-order loss rate constant of $\mathrm{NH}_{3}$. An example of the fit is shown by the black trace in Fig. 3b.

The average $\mathrm{NH}_{3}$ loss rate constant on dew nights was $1.33 \pm 0.5 \times 10^{-4} \mathrm{~s}^{-1}$ compared to $1.35 \pm 0.3 \times 10^{-4} \mathrm{~s}^{-1}$ on dry nights. In other words, there is no significant difference in the rate of $\mathrm{NH}_{3}$ loss on dew vs. non-dew nights. This implies that dew does not actually enhance $\mathrm{NH}_{3}$ deposition under these conditions, suggesting that the aerodynamic and quasilaminar resistances dominate over surface resistances. The average nocturnal wind speed on dew nights was lower than on dry nights $\left(1.3 \mathrm{~m} \mathrm{~s}^{-1}\right.$ vs. $\left.2.2 \mathrm{~m} \mathrm{~s}^{-1}\right)$. Lower wind speeds typically result in a higher $R_{\mathrm{a}}$ and $R_{\mathrm{b}}$. It is possible that increased aerodynamic and quasi-laminar resistances on dew nights are partially compensated for by a lower surface resistance due to dew, such that the overall canopy resistance is similar on dew nights and dry nights. Average nocturnal wind direction was from the northwest (i.e. downslope flow) on both dew nights $\left(307^{\circ}\right)$ and dry nights $\left(313^{\circ}\right)$. The average nocturnal maximum for RH was $75 \%$ on dew nights and only $53 \%$ on dry nights. The lower wind speeds and higher RH on dew nights are consistent with the meteorological conditions favourable for dew formation.

Deposition of $\mathrm{NH}_{3}$ on dry nights could be to either leaf cuticles and/or soil pore water. However, it is not possible to unambiguously attribute the nocturnal $\mathrm{NH}_{3}$ loss solely to deposition. Enhanced downslope flow of cleaner air on dry nights cannot be ruled out as a contributor to nocturnal $\mathrm{NH}_{3}$ loss. Since $\mathrm{NH}_{3}$ deposition is independent of dew amount, there could be a large discrepancy between $\left[\mathrm{NH}_{4}^{+}\right]$for dew on the dewmeter vs. the dew collector if $V_{\text {dew }}$ is significantly different on the two surfaces. However, the campaign averages of $V_{\text {dew }}$ on the dewmeter (Table 1) are within $10 \%$ of 
dew volume obtained off the collector (data not shown) so $\left[\mathrm{NH}_{4}^{+}\right]$is likely similar for dew on both platforms.

Since most of the $\mathrm{NH}_{4}^{+}$in dew volatilizes and the presence of dew does not affect $\mathrm{NH}_{3}$ deposition overnight, the net impact is a reduction in the overall removal of $\mathrm{NH}_{3}$. As a result, the atmospheric lifetime and range of $\mathrm{NH}_{3}$ transport will be extended.

\subsection{Potential Influence from rain evaporation}

Numerous studies have reported rapid increases of nearsurface $\mathrm{NH}_{3}$ within 1-2 h after some rain events (e.g. Cooter et al., 2010; Walker et al., 2013; Wentworth et al., 2014). Given the findings discussed in the previous section, one possible explanation is the emission of $\mathrm{NH}_{3}$ from drying rain droplets. However, unlike dew, some difficult-to-predict fraction of rain will permeate through the soil, thus preventing or delaying the release of $\mathrm{NH}_{3}$. Nonetheless, we attempt to qualitatively explore this hypothesis by examining the Frac $\left(\mathrm{NH}_{3}\right)$ of four rain samples collected at RMNP as well as the behaviour of $\mathrm{NH}_{3}$ during rainfall evaporation. Rain samples were collected with the same procedure used to collect dew, which differs from the usual method of capturing precipitation via an automated precipitation bucket (e.g. Benedict et al., 2013a). The precipitation bucket is normally equipped with an $\mathrm{O}$ ring and lid to prevent dry deposition and dissolution of water-soluble gases when it is not precipitating. However, precipitation on the dew collector surface was left exposed and its composition is influenced by dry deposition and gas-phase dissolution until it was collected at the onset of evaporation.

Table S2 in the Supplement gives the concentration of ions measured in rain samples. In general, concentrations of ions are comparable between dew and rain samples, with the exception of $\mathrm{NH}_{4}^{+}, \mathrm{SO}_{4}^{2-}$, and $\mathrm{NO}_{3}^{-}$, which are a factor of 2-4 times more concentrated in rain samples. The enhancement of these species in rain may reflect additional in-cloud and below-cloud scavenging of gases $\left(\mathrm{NH}_{3}, \mathrm{HNO}_{3}\right.$, and $\left.\mathrm{SO}_{2}\right)$ and $\mathrm{PM}_{2.5}$ aloft. Another possibility is that rain generally forms during upslope conditions which coincide with more polluted air masses from east of RMNP, whereas dew typically forms during downslope (cleaner) conditions. Numerous studies have compared dew composition to rain composition and, in general, have found that concentrations are enhanced in dew relative to rain (e.g. Polkowska et al., 2008; Wagner et al., 1992). However, Pierson et al. (1986) reported dew composition to be similar to, but more dilute than, rain at a rural site in Pennsylvania.

Table S3 shows the TOC, IC, TN, pH, and calculated Frac $\left(\mathrm{NH}_{3}\right)$ for the four rain samples. Rain samples were more acidic (average $\mathrm{pH}=4.54$ ) than dew samples (average $\mathrm{pH}=5.19)$. The average $\mathrm{Frac}\left(\mathrm{NH}_{3}\right)$ for rain samples was 0.66 suggesting that, on average, roughly two-thirds of $\mathrm{NH}_{4}^{+}$contained in precipitation on surfaces should be liberated as $\mathrm{NH}_{3}$ upon evaporation. This could pose a significant flux of $\mathrm{NH}_{3}$ to the boundary layer; however, since the fraction of rain that remains on surfaces after rainfall where it can readily evaporate is not constrained, only an upper estimate on $\mathrm{NH}_{3}$ fluxes from drying rain can be calculated $\left(21.2 \pm 13 \mathrm{ng} \mathrm{m}^{-2} \mathrm{~s}^{-1}\right)$. This value was calculated in same manner as the dew samples and assumes all rainfall evaporates.

Figure 6 shows time series of rain accumulation $\left(\mathrm{g} \mathrm{m}^{-2}\right)$, air temperature $\left({ }^{\circ} \mathrm{C}\right.$ ), and $\mathrm{NH}_{3}$ mixing ratio (ppbv) on 4 separate days with observed rainfall. The rain accumulation was measured with the dewmeter; $1000 \mathrm{~g} \mathrm{~m}^{-2}$ of accumulation is equivalent to $1 \mathrm{~mm}$ of rainfall. Rainfall in excess of $2000 \mathrm{~g} \mathrm{~m}^{-2}$ flooded the collection tray and could not be reliably recorded by the dewmeter. On 24 June (Fig. 6a) there were three light rainfalls at 15:00, 16:00, and 19:00. The first event at 15:00 was accompanied by a rapid decrease in $\mathrm{NH}_{3}$ likely due to scavenging by rain droplets; however, this was not observed for the other two rainfalls that day. For the second rain event in Fig. 6a (at 16:00) a substantial increase in $\mathrm{NH}_{3}$ (from 0.5 to $1.5 \mathrm{ppbv}$ ) was observed during evaporation and is consistent with $\mathrm{NH}_{3}$ liberation from evaporating rain. However, evaporation of the other rain events on 24 June (Fig. 6a) as well as those on 27 June (Fig. 6b) and 11 July (Fig. 6c) is not associated with concomitant increases in $\mathrm{NH}_{3}$, implying that these rain evaporation events did not release $\mathrm{NH}_{3}$. The evaporation of a more substantial rainfall on 13 August (Fig. 6d) is associated with a temporary rise in $\mathrm{NH}_{3}$ until evaporation ceases at sundown. The instances of rain evaporation not associated with $\mathrm{NH}_{3}$ increases could be due to rain with a low Frac $\left(\mathrm{NH}_{3}\right)$, an insignificant amount of $\mathrm{NH}_{4}^{+}$in the rain, more atmospheric dilution than dew mornings due to higher turbulence, and/or significant rain penetration into the soil.

The results from Fig. 6 are consistent with previous literature showing $\mathrm{NH}_{3}$ increase immediately following only some rainfall events (Cooter et al., 2010; Walker et al., 2013; Wentworth et al., 2014). The timing of some rain evaporation events with $\mathrm{NH}_{3}$ increases, as well as the high $\operatorname{Frac}\left(\mathrm{NH}_{3}\right)$ (average $=0.66$ ) of the four measured rain samples, suggests it is possible for rain evaporation from surfaces to be a substantial source of $\mathrm{NH}_{3}$. Neirynck and Ceulemans (2008) reported $\mathrm{NH}_{3}$ increases concomitant with a drying forest canopy (after rainfall) as measured by a leaf wetness sensor.

Currently, all $\mathrm{NH}_{4}^{+}$collected in precipitation samples is counted towards $\mathrm{N}$ deposition. However, if a fraction of $\mathrm{NH}_{4}^{+}$ in rainfall is emitted as $\mathrm{NH}_{3}$ during evaporation then $\mathrm{N}$ deposition could be overestimated. At RMNP, wet deposition of $\mathrm{NH}_{x}$ and dry deposition of $\mathrm{NH}_{3}$ account for 35 and $18 \%$ respectively of total reactive nitrogen deposition to the site (Benedict et al., 2013a). This budget does not take into account any re-emission of $\mathrm{NH}_{3}$ from drying rain. This budget also does not explicitly account for ammonia uptake or emission during dew formation and evaporation. A more extensive suite of dew and rainfall measurements is necessary 


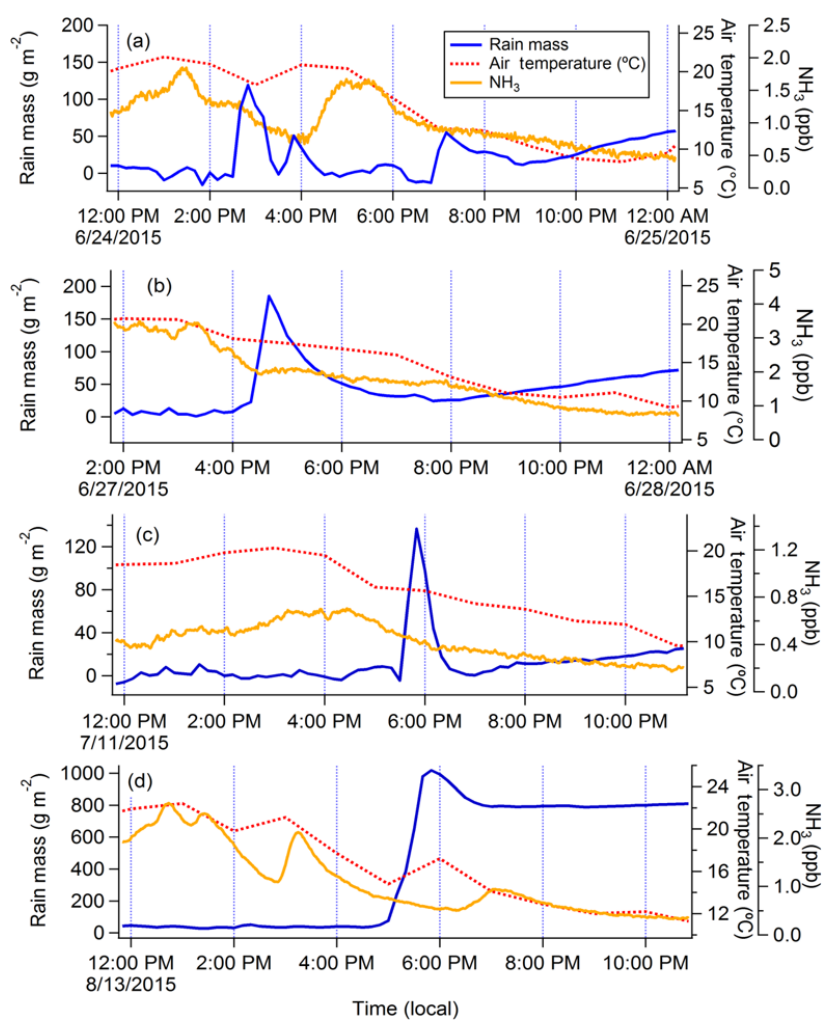

Figure 6. Rain accumulation (blue, $\mathrm{g} \mathrm{m}^{-2}$ ), $\mathrm{NH}_{3}$ mixing ratio (orange, ppbv), and air temperature (red, ${ }^{\circ} \mathrm{C}$ ) during the afternoon and evening on a) 24 June, (b) 27 June, (c) 11 July, and (d) 13 August $2015 ; 100 \mathrm{~g} \mathrm{~m}^{-2}$ is equivalent to $0.1 \mathrm{~mm}$ of rain.

to quantify the impact of evaporation on annual N-deposition budgets at RMNP.

\subsection{Implications for other Gases}

Other water-soluble gases with similar or larger effective Henry's law constants $\left(K_{\mathrm{H}}^{\text {eff }}\right)$ to $\mathrm{NH}_{3}$ are likely influenced by dew and rain evaporation as well, provided that the relative abundance of counterions allows for volatilization during evaporation. $K_{\mathrm{H}}^{\mathrm{eff}}$ is the equilibrium constant for describing gas-aqueous partitioning and accounts for chemical equilibria in solution. Since acid-base equilibria are $\mathrm{pH}$ dependent, then the $K_{\mathrm{H}}^{\text {eff }}$ for acidic and basic species is also $\mathrm{pH}$ dependent (Sander, 2015). $K_{\mathrm{H}}^{\text {eff }}$ of $\mathrm{NH}_{3}$ was calculated for the 12 dew samples using data from Sander (2015) to determine the temperature-dependent Henry's law constant $\left(K_{\mathrm{H}}\right)$ and from Bates and Pinching (1950) for the temperaturedependent acid dissociation constant $\left(K_{\mathrm{a}}\right)$ of $\mathrm{NH}_{4}^{+}$required for the calculation of $K_{\mathrm{H}}^{\text {eff }}$. During the study, dew $K_{\mathrm{H}}^{\text {eff }}$ spanned 2 orders of magnitude and ranged from $4.5 \times 10^{5}$ to $2.7 \times 10^{7} \mathrm{M} \mathrm{atm}^{-1}$. These high values are indicative of the high water solubility of $\mathrm{NH}_{3}$ at the observed pHs and temperatures. Chameides (1987) used a simple resistance model to show that deposition of gas-phase species with
$K_{\mathrm{H}}^{\text {eff }}>10^{5} \mathrm{M} \mathrm{atm}^{-1}$ to wetted surfaces (i.e. dew) will be limited by the aerodynamic resistance since the surface resistance is negligible for such highly water-soluble species. In other words, it is likely that dew will be a significant nighttime sink for other trace gas species with $K_{\mathrm{H}}^{\text {eff }}>10^{5} \mathrm{M} \mathrm{atm}^{-1}$ since the dissolution into dew is controlled by aerodynamic processes independent of the identity of the gas.

Table 1 shows the ratio of $\left[\mathrm{NH}_{4}^{+}\right]$measured in dew to the concentration predicted from equilibrium calculations using $K_{\mathrm{H}}^{\text {eff }}$ and measured $\mathrm{NH}_{3}$ mixing ratio at the onset of evaporation. The average ratio is low (0.04), consistent with a significant aerodynamic resistance that prevents $\mathrm{NH}_{4}^{+}$saturation in dew droplets overnight.

It has been suggested that dew can act as a reservoir for phenol, nitrophenols, formaldehyde, and HONO based on observations of these species in dew in Santiago, Chile $(\mathrm{Ru}-$ bio et al., 2009, 2012). Zhou et al. (2002) found a correlation between high night-time $\mathrm{RH}$ (a surrogate for dew formation) and HONO increases the following morning coincident with a decrease in RH. A follow-up study (He et al., 2006) confirmed aqueous solutions mimicking dew can release $>90 \%$ of $\mathrm{NO}_{2}^{-}$as $\mathrm{HONO}$ upon evaporation and observed similar HONO pulses during canopy drying at a rural forest site in Michigan. Indeed, there is some evidence in the literature that water-soluble gases (primarily HONO) exhibit a similar behaviour to $\mathrm{NH}_{3}$ during dew formation and evaporation observed in this study.

Table 2 shows the calculated $K_{\mathrm{H}}^{\mathrm{eff}}$ (at $10^{\circ} \mathrm{C}$ ) for common water-soluble gases that could be influenced by dew formation/evaporation. This table is by no means exhaustive, but it highlights the important role dew may have as a night-time reservoir and morning source for gases other than $\mathrm{NH}_{3}$. Formic acid $(\mathrm{HCOOH})$, acetic acid $\left(\mathrm{CH}_{3} \mathrm{COOH}\right)$, nitrous acid $(\mathrm{HONO})$, and nitric acid $\left(\mathrm{HNO}_{3}\right)$ all have increasing $K_{\mathrm{H}}^{\mathrm{eff}}$ with increasing $\mathrm{pH}$ since a more basic solution will promote dissociation of the acid into its conjugate base. The average $\mathrm{pH}$ of dew at $\mathrm{RMNP}(\sim 5.2)$ is likely sufficiently acidic for HONO to experience a surface resistance $\left(K_{\mathrm{H}}^{\mathrm{eff}} \ll 10^{5} \mathrm{M} \mathrm{atm}^{-1}\right)$, which would limit its transport across the dew-air interface. This is consistent with the low average $\left[\mathrm{NO}_{2}^{-}\right](0.2 \mu \mathrm{M})$ in dew at RMNP, although this might simply reflect low HONO mixing ratios at the remote RMNP site.

Future field studies on these species should include simultaneous measurements of dew composition, dew amount, and gas-phase mixing ratios to determine whether dew is an important night-time reservoir and morning source. The latter will be dependent on the fraction of gas released upon dew evaporation, which requires further investigation specific to each gas. Based on the findings in this work and Takenaka et al. (2009) it is likely that acidic semi-volatiles (e.g. acetic acid, formic acid, HONO) will be retained as salts during dew evaporation at RMNP due to the excess of cations. 
Table 2. $K_{\mathrm{H}}^{\text {eff }}$ of $\mathrm{NH}_{3}$ and other water-soluble gases at $10^{\circ} \mathrm{C}$ and various $\mathrm{pHs}$.

\begin{tabular}{lrc}
\hline Gas & $\mathrm{pH}$ & $K_{\mathrm{H}}^{\text {eff }}$ \\
\hline $\mathrm{NH}_{3}$ (ammonia) & 4.5 & $2.1 \times 10^{7}$ \\
& 6 & $6.7 \times 10^{5}$ \\
& 7.5 & $2.1 \times 10^{4}$ \\
\hline $\mathrm{HCOOH}$ (formic acid) & 4.5 & $1.1 \times 10^{5}$ \\
& 6 & $2.8 \times 10^{6}$ \\
& 7.5 & $8.9 \times 10^{7}$ \\
\hline $\mathrm{CH}_{3} \mathrm{COOH}$ (acetic acid) & 4.5 & $1.9 \times 10^{4}$ \\
& 6 & $2.3 \times 10^{5}$ \\
& 7.5 & $7.0 \times 10^{6}$ \\
\hline $\mathrm{HONO}^{2}$ (nitrous acid) & 4.5 & $1.3 \times 10^{3}$ \\
& 6 & $3.9 \times 10^{4}$ \\
& 7.5 & $1.2 \times 10^{6}$ \\
\hline $\mathrm{HNO}_{3}$ (nitric acid) & 4.5 & $5.3 \times 10^{12}$ \\
& 6 & $1.7 \times 10^{14}$ \\
& 7.5 & $5.3 \times 10^{15}$ \\
\hline
\end{tabular}

\section{Conclusions}

Laboratory experiments involving synthetic dew were performed to determine the factor(s) controlling the fraction of $\mathrm{NH}_{4}^{+}$released as $\mathrm{NH}_{3}$ upon dew evaporation. Results were mostly consistent with Takenaka et al. (2009), who found that the amount of $\mathrm{NH}_{3}$ that volatilized from drying aqueous solutions is governed by the relative abundances of $\mathrm{NH}_{4}^{+}$and excess "non-volatile" anions ( $\Sigma$ anions $-\sum$ cations). However, our findings suggest that acetate, formate, and $\mathrm{HCO}_{3}^{-}$ should also be counted towards the anion budget. Hence, the Frac $\left(\mathrm{NH}_{3}\right)$ released from a drying dew sample can be predicted given the ionic composition and $\mathrm{pH}$.

A dewmeter (for dew amount, deployed continuously from 22 June to 31 August) and dew collector (for dew composition, deployed successfully on 12 occasions) were set up at a remote field site in Colorado. Dew was relatively dilute compared to previous studies and had an average $\left[\mathrm{NH}_{4}^{+}\right]$of $26 \mu \mathrm{M}$ and $\mathrm{pH}$ of 5.2 at sunrise. Simple calculations revealed that dew can act as a significant night-time reservoir of $\mathrm{NH}_{3}$. At the onset of dew evaporation there was, on average, roughly twice as much $\mathrm{NH}_{4}^{+}$in dew as $\mathrm{NH}_{3}$ in the boundary layer. Furthermore, the observed $\mathrm{NH}_{3}$ loss overnight was roughly equivalent to the amount of $\mathrm{NH}_{4}^{+}$that accumulated in dew by sunrise. Dew composition was used to calculate an average $\operatorname{Frac}\left(\mathrm{NH}_{3}\right)$ of 0.94 , suggesting that the vast majority of $\mathrm{NH}_{3}$ sequestered in dew overnight is emitted during evaporation shortly after sunrise. Mornings with dew experience a large increase in $\mathrm{NH}_{3}$ coincident with dew evaporation. Once the dew has completely evaporated, $\mathrm{NH}_{3}$ mixing ratios either plateau or decrease. Fluxes of $\mathrm{NH}_{3}$ from dew averaged
$6.2 \pm 5 \mathrm{ng} \mathrm{m}^{-2} \mathrm{~s}^{-1}$ during evaporation and were calculated using measured $\left[\mathrm{NH}_{4}^{+}\right], V_{\text {dew }}, t_{\text {evap }}$, and $\operatorname{Frac}\left(\mathrm{NH}_{3}\right)$. These fluxes are substantial compared to previously reported fluxes in non-fertilized grasslands (Wentworth et al., 2014; Wichink Kruit et al., 2007). Mornings without any surface wetness (neither dew nor rain) never experienced a sharp increase in $\mathrm{NH}_{3}$. Dew-related $\mathrm{NH}_{3}$ fluxes are likely much more substantial in urban and agricultural areas where $\mathrm{NH}_{3}$ and $\left[\mathrm{NH}_{4}^{+}\right]$in dew are significantly higher than at RMNP.

Morning increases of $\mathrm{NH}_{3}$ frequently observed at RMNP (and other sites) are very likely the result of $\mathrm{NH}_{3}$ emissions during dew evaporation. This hypothesis is supported by (1) coincident timing of morning $\mathrm{NH}_{3}$ increases/decreases at the start/completion of dew evaporation, (2) lack of $\mathrm{NH}_{3}$ morning increase on every non-dew morning, (3) significant $\mathrm{NH}_{3}$ fluxes calculated from dew, (4) relative abundances of $\mathrm{NH}_{4}^{+}$in dew and $\mathrm{NH}_{3}$ in the boundary layer, and (5) approximate mass balance closure between $\mathrm{NH}_{3}$ lost overnight and $\mathrm{NH}_{4}^{+}$accumulated in dew. The phenomenon of dew "recycling" atmospheric $\mathrm{NH}_{3}$ could lead to an overestimation of $\mathrm{NH}_{3}$ dry deposition in some ecosystems since dew formed overnight can take up much of the near-surface ammonia and then release most of it again in the morning upon evaporation. Such phenomena are generally not considered in current models of $\mathrm{NH}_{3}$ dry deposition. In addition, nocturnal loss rates of $\mathrm{NH}_{3}$ were unaffected by the presence of dew. Our results suggest the net effect of dew is to reduce the overall removal of $\mathrm{NH}_{3}$ and prolong its atmospheric lifetime as long as the dew composition yields a high $\operatorname{Frac}\left(\mathrm{NH}_{3}\right)$.

Similar behaviour (coincident timing of $\mathrm{NH}_{3}$ increases and evaporation) was occasionally observed for rain. Analysis of four rain samples yielded an average $\operatorname{Frac}\left(\mathrm{NH}_{3}\right)$ of 0.66 , suggesting $\mathrm{NH}_{3}$ can be released from evaporation of rain in RMNP as well. However, due to the limited number of samples and lack of constraint for amount of rain sequestered below ground it is currently impossible to be even semiquantitative about potential $\mathrm{NH}_{3}$ fluxes from rain evaporation. This uncertainty merits further research since $\mathrm{NH}_{x}$ wet deposition does not account for re-release of $\mathrm{NH}_{3}$ from evaporation. Subsequent studies should also examine (1) the role of biological processes on surface water composition (e.g. stomatal exchange, modification via microbes) and (2) influence of guttation (leaf exudate) on surface-air $\mathrm{NH}_{3}$ exchange.

Additional field measurements quantifying $\mathrm{NH}_{3}$ release from dew and rain evaporation are needed to determine how relevant these phenomena are for modulating $\mathrm{NH}_{3}$ mixing ratios and $\mathrm{N}$ deposition in different environments (e.g. urban, rural, agricultural). Although the majority of $\mathrm{NH}_{4}^{+}$in dew was released back to the atmosphere at RMNP, this is not necessarily the case at other locations. For instance, environments with $\mathrm{HNO}_{3}$ deposition exceeding $\mathrm{NH}_{3}$ deposition to dew would cause a low (or zero) Frac $\left(\mathrm{NH}_{3}\right)$. In addition, a tall canopy can recapture near-surface $\mathrm{NH}_{3}$ emissions and might modulate emissions from dew drying in the lower 
canopy (Walker et al., 2013). Regardless, the ability for dew to act as a morning source of $\mathrm{NH}_{3}$ is currently absent from atmospheric models, with the exception of a few field-scale models based on the work of Flechard et al. (1999). The observations from this study suggest dew imparts a large influence on boundary layer $\mathrm{NH}_{3}$; hence, future work should also focus on developing model parameterizations for $\mathrm{NH}_{3}$ uptake during dew formation and release from evaporating dew.

To our knowledge, this is the first study to quantitatively examine the influence of dew on any water-soluble gas by simultaneously measuring dew amount, dew composition, and atmospheric composition. Although $\mathrm{NH}_{3}$ is the focus of this work, gases with similar $K_{\mathrm{H}}^{\text {eff }}\left(>10^{5} \mathrm{M} \mathrm{atm}^{-1}\right.$ ) might be influenced by dew formation and evaporation in a comparable manner. Such species include, but are not limited to, acetic acid, formic acid, $\mathrm{HONO}$, and $\mathrm{HNO}_{3}$. Methodology similar to this study should be used to conduct quantitative field studies for the aforementioned species to better understand the dynamic influence of dew on boundary layer composition.

\section{Data availability}

Hourly averaged meteorology data for the field site (ROMOLP) are available from the National Park Service (NPS, 2016) at http://ard-request.air-resource.com/data.aspx. Underlying data not given in the paper or on the NPS website can be accessed by contacting the corresponding author.

\section{The Supplement related to this article is available online at doi:10.5194/acp-16-7435-2016-supplement.}

Acknowledgements. The National Park Service (NPS) maintained the field site, provided meteorological data, and supported the costs of field and laboratory measurements. Gregory R. Wentworth acknowledges funding from NSERC and the Integrating Atmospheric Chemistry and Physics from Earth to Space (IACPES) program for travel funding. The authors wish to thank C. Wallesen, G. Perry, and the staff at the Saddle \& Surrey Motel in Estes Park, CO, for providing generously discounted rates during peak tourist season. Lastly, R. Clark and J. Price, and H. Guan provided valuable insight on construction of the dewmeter and dew collector respectively.

Edited by: S. E. Pusede

\section{References}

Baldridge, A. M., Hook, S. J., Grove, C. I., and Rivera, G.: The aster spectral library version 2.0, Remote Sens. Environ., 113, 711-715, doi:10.1016/j.rse.2008.11.007, 2009.
Baron, J. S.: Hindcasting nitrogen deposition to determine an ecological critical load, Ecol. Appl., 16, 433-439, 2006.

Bash, J. O., Walker, J. T., Katul, G. G., Jones, M. R., Nemitz, E., and Robarge, W. P.: Estimation of In-Canopy Ammonia Sources and Sinks in a Fertilized Zea mays Field, Environ. Sci. Technol., 44, 1683-1689, 2010.

Bash, J. O., Cooter, E. J., Dennis, R. L., Walker, J. T., and Pleim, J. E.: Evaluation of a regional air-quality model with bidirectional $\mathrm{NH}_{3}$ exchange coupled to an agroecosystem model, Biogeosciences, 10, 1635-1645, doi:10.5194/bg-10-1635-2013, 2013.

Bates, R. G. and Pinching, G. D.: Dissociation Constant of Aqueous Ammonia at 0 to $50^{\circ}$ from E. m. f. Studies of the Ammonium Salt of a Weak Acid, J. Am. Chem. Soc., 72, 1393-1396, doi:10.1021/ja01159a087, 1950.

Beem, K. B., Raja, S., Schwandner, F. M., Taylor, C., Lee, T., Sullivan, A. P., Carrico, C. M., McMeeking, G. R., Day, D., Levin, E., Hand, J., Kreidenweis, S. M., Schichtel, B., Malm, W. C., and Collett, J. L.: Deposition of reactive nitrogen during the Rocky Mountain Airborne Nitrogen and Sulfur (RoMANS) study, Environ. Pollut., 158, 862-872, doi:10.1016/j.envpol.2009.09.023, 2010.

Benedict, K. B., Carrico, C. M., Kreidenweis, S. M., Schichtel, B., Malm, W. C., and Collett, J. L.: A seasonal nitrogen deposition budget for Rocky Mountain National Park, Ecol. Appl., 23, 1156-1169, doi:10.1890/12-1624.1, 2013a.

Benedict, K. B., Day, D., Schwandner, F. M., Kreidenweis, S. M., Schichtel, B., Malm, W. C., and Collett, J. L.: Observations of atmospheric reactive nitrogen species in Rocky Mountain National Park and across northern Colorado, Atmos. Environ., 64, 66-76, doi:10.1016/j.atmosenv.2012.08.066, 2013b.

Bowman, W. D., Murgel, J., Blett, T., and Porter, E.: Nitrogen critical loads for alpine vegetation and soils in Rocky Mountain National Park, J. Environ. Manage., 103, 165-171, doi:10.1016/j.jenvman.2012.03.002, 2012.

Burkhardt, J., Flechard, C. R., Gresens, F., Mattsson, M., Jongejan, P. A. C., Erisman, J. W., Weidinger, T., Meszaros, R., Nemitz, E., and Sutton, M. A.: Modelling the dynamic chemical interactions of atmospheric ammonia with leaf surface wetness in a managed grassland canopy, Biogeosciences, 6, 67-84, doi:10.5194/bg-667-2009, 2009.

Chameides, W. L.: Acid dew and the role of chemistry in the dry deposition of reactive gases to wetted surfaces, J. Geophys. Res., 92, 11895-11908, 1987.

Cooter, E. J., Bash, J. O., Walker, J. T., Jones, M. R., and Robarge, W.: Estimation of $\mathrm{NH}_{3}$ bi-directional flux from managed agricultural soils, Atmos. Environ., 44, 2107-2115, doi:10.1016/j.atmosenv.2010.02.044, 2010.

Ellis, R. A., Murphy, J. G., Markovic, M. Z., VandenBoer, T. C., Makar, P. A., Brook, J., and Mihele, C.: The influence of gasparticle partitioning and surface-atmosphere exchange on ammonia during BAQS-Met, Atmos. Chem. Phys., 11, 133-145, doi:10.5194/acp-11-133-2011, 2011.

Flechard, C., Fowler, D., Sutton, M. A., and Cape, J. N.: A dynamic chemical model of bi-directional ammonia exchange between semi-natural vegetation and the atmosphere, Q. J. Roy. Meteor. Soc., 125, 2611-2641, doi:10.1002/qj.49712555914, 1999.

Fowler, D., Pilegaard, K., Sutton, M. A., Ambus, P., Raivonen, M., Duyzer, J., Simpson, D., Fagerli, H., Fuzzi, S., Schjoerring, J. K., Granier, C., Neftel, A., Isaksen, I. S. A., Laj, P., Maione, M., 
Monks, P. S., Burkhardt, J., Daemmgen, U., Neirynck, J., Personne, E., Wichink-Kruit, R., Butterbach-Bahl, K., Flechard, C., Tuovinen, J. P., Coyle, M., Gerosa, G., Loubet, B., Altimir, N., Gruenhage, L., Ammann, C., Cieslik, S., Paoletti, E., Mikkelsen, T. N., Ro-Poulsen, H., Cellier, P., Cape, J. N., Horváth, L., Loreto, F., Niinemets, Ü., Palmer, P. I., Rinne, J., Misztal, P., Nemitz, E., Nilsson, D., Pryor, S., Gallagher, M. W., Vesala, T., Skiba, U., Brüggemann, N., Zechmeister-Boltenstern, S., Williams, J., O’Dowd, C., Facchini, M. C., de Leeuw, G., Flossman, A., Chaumerliac, N., and Erisman, J. W.: Atmospheric composition change: Ecosystems-Atmosphere interactions, Atmos. Environ., 43, 5193-5267, doi:10.1016/j.atmosenv.2009.07.068, 2009.

Gong, L., Lewicki, R., Griffin, R. J., Flynn, J. H., Lefer, B. L., and Tittel, F. K.: Atmospheric ammonia measurements in Houston, TX using an external-cavity quantum cascade laser-based sensor, Atmos. Chem. Phys., 11, 9721-9733, doi:10.5194/acp-11-97212011, 2011.

Grimmond, C. S. B., Isard, S. A., and Belding, M. J.: Development and evaluation of continuously weighing mini-lysimeters, Agr. Forest Meteorol., 62, 205-218, doi:10.1016/01681923(92)90015-V, 1992.

Guan, H., Sebben, M., and Bennett, J.: Radiative- and artificial-cooling enhanced dew collection in a coastal area of South Australia, Urban Water J., 11, 175-184, doi:10.1080/1573062X.2013.765494, 2014.

He, Y., Zhou, X., Hou, J., Gao, H., and Bertman, S. B.: Importance of dew in controlling the air-surface exchange of HONO in rural forested environments, Geophys. Res. Lett., 33, L02813, doi:10.1029/2005GL024348, 2006.

Herckes, P., Chang, H., Lee, T., and Collett, J. L.: Air pollution processing by radiation fogs, Water. Air. Soil Pollut., 181, 6575, doi:10.1007/s11270-006-9276-x, 2007.

Herckes, P., Valsaraj, K. T., and Collett, J. L.: A review of observations of organic matter in fogs and clouds: Origin, processing and fate, Atmos. Res., 132-133, 434-449, 2013.

Krupa, S. V.: Effects of atmospheric ammonia $\left(\mathrm{NH}_{3}\right)$ on terrestrial vegetation: A review, Environ. Pollut., 124, 179-221, doi:10.1016/S0269-7491(02)00434-7, 2003.

Lekouch, I., Mileta, M., Muselli, M., Milimouk-Melnytchouk, I., Šojat, V., Kabbachi, B., and Beysens, D.: Comparative chemical analysis of dew and rain water, Atmos. Res., 95, 224-234, doi:10.1016/j.atmosres.2009.10.002, 2010.

Löflund, M., Kasper-Giebl, A., Stopper, S., Urban, H., Biebl, P., Kirchner, M., Braeutigam, S., and Puxbaum, H.: Monitoring ammonia in urban, inner alpine and pre-alpine ambient air, J. Environ. Monitor., 4, 205-209, doi:10.1039/b109727j, 2002.

Martin, S. T., Hung, H.-M., Park, R. J., Jacob, D. J., Spurr, R. J. D., Chance, K. V., and Chin, M.: Effects of the physical state of tropospheric ammonium-sulfate-nitrate particles on global aerosol direct radiative forcing, Atmos. Chem. Phys., 4, 183214, doi:10.5194/acp-4-183-2004, 2004.

Massad, R.-S., Nemitz, E., and Sutton, M. A.: Review and parameterisation of bi-directional ammonia exchange between vegetation and the atmosphere, Atmos. Chem. Phys., 10, 10359-10386, doi:10.5194/acp-10-10359-2010, 2010.

Moro, M. J., Were, A., Villagarcía, L., Cantón, Y., and Domingo, F.: Dew measurement by Eddy covariance and wetness sensor in a semiarid ecosystem of SE Spain, J. Hydrol., 335, 295-302, doi:10.1016/j.jhydrol.2006.11.019, 2007.

Munger, J. W., Collett, J., Daube, B. C., and Hoffmann, M. R.: Carboxylic acids and carbonyl compounds in southern California clouds and fogs, Tellus B, 41, 230-242, doi:10.1111/j.16000889.1989.tb00303.x, 1989.

Nanus, L., Clow, D. W., Saros, J. E., Stephens, V. C., and Campbell, D. H.: Mapping critical loads of nitrogen deposition for aquatic ecosystems in the Rocky Mountains, USA, Environ. Pollut., 166, 125-135, doi:10.1016/j.envpol.2012.03.019, 2012.

NPS (National Park Service): Validated meteorological data, available at: http://ard-request.air-resource.com/data.aspx, last access: 2 January 2016.

Neirynck, J. and Ceulemans, R.: Bidirectional ammonia exchange above a mixed coniferous forest, Environ. Pollut., 154, 424-438, doi:10.1016/j.envpol.2007.11.030, 2008.

Nowak, J. B., Huey, L. G., Russell, A. G., Tian, D., Neuman, J. A., Orsini, D., Sjostedt, S. J., Sullivan, A. P., Tanner, D. J., Weber, R. J., Nenes, A., Edgerton, E., and Fehsenfeld, F. C.: Analysis of urban gas phase ammonia measurements from the 2002 Atlanta Aerosol Nucleation and Real-Time Characterization Experiment (ANARChE), J. Geophys. Res., 111, D17308, doi:10.1029/2006JD007113, 2006.

Okochi, H., Kajimoto, T., Arai, Y., and Igawa, M.: Effect of Acid Deposition on Urban Dew Chemistry in Yokohama, Japan, B. Chem. Soc. Jpn., 69, 3355-3365, 1996.

Okochi, H., Sato, E., Matsubayashi, Y., and Igawa, M.: Effect of atmospheric humic-like substances on the enhanced dissolution of volatile organic compounds into dew water, Atmos. Res., 87, 213-223, doi:10.1016/j.atmosres.2007.11.003, 2008.

Petters, M. D. and Kreidenweis, S. M.: A single parameter representation of hygroscopic growth and cloud condensation nucleus activity, Atmos. Chem. Phys., 7, 1961-1971, doi:10.5194/acp-71961-2007, 2007.

Pierson, W. R., Brachaczek, W. W., Gorse, R. A., Japar, S. M., and Norbeck, J. M.: On the acidity of dew, J. Geophys. Res., 91, 4083, doi:10.1029/JD091iD03p04083, 1986.

Polkowska, Z., Błaś, M., Klimaszewska, K., Sobik, M., Małk, S., and Namieśnik, J.: Chemical characterization of dew water collected in different geographic regions of Poland, Sensors, 8, 4006-4032, doi:10.3390/s8064006, 2008.

Pope, C. A., Burnett, R. T., Thun, M. J., Calle, E. E., Krewski, D., and Thurston, G. D.: Lung cancer, cardiopulmonary mortality, and long-term exposure to fine particulate air pollution, J. Am. Med. Assoc., 287, 1132-1141, 2002.

Price, J. D. and Clark, R.: On the Measurement of Dewfall and Fog-Droplet Deposition, Bound.-Lay. Meteorol., 152, 367-393, doi:10.1007/s10546-014-9930-6, 2014.

Reis, S., Pinder, R. W., Zhang, M., Lijie, G., and Sutton, M. A.: Reactive nitrogen in atmospheric emission inventories, Atmos. Chem. Phys., 9, 7657-7677, doi:10.5194/acp-9-7657-2009, 2009.

Richards, K.: Observation and simulation of dew in rural and urban environments, Prog. Phys. Geogr., 28, 76-94, doi:10.1191/0309133304pp402ra, 2004.

Rubio, M. A., Lissi, E., Villena, G., Elshorbany, Y. F., Kleffmann, J., Kurtenbach, R., and Wiesen, P.: Simultaneous measurements of formaldehyde and nitrous acid in dews and gas phase in the 
atmosphere of Santiago, Chile, Atmos. Environ., 43, 6106-6109, doi:10.1016/j.atmosenv.2009.09.017, 2009.

Rubio, M. A., Lissi, E., Herrera, N., Pérez, V., and Fuentes, N.: Phenol and nitrophenols in the air and dew waters of Santiago de Chile, Chemosphere, 86, 1035-1039, doi:10.1016/j.chemosphere.2011.11.046, 2012.

Sander, R.: Compilation of Henry's law constants (version 4.0) for water as solvent, Atmos. Chem. Phys., 15, 4399-4981, doi:10.5194/acp-15-4399-2015, 2015.

Seinfeld, J. H. and Pandis, S. N.: Atmospheric Chemistry and Physics: From Air Pollution to Climate Change, 2nd Edn., John Wiley \& Sons, Toronto, 2006.

Singh, S. P., Khare, P., Kumari, K. M., and Srivastava, S. S.: Chemical characterization of dew at a regional representative site of North-Central India, Atmos. Res., 80, 239-249, doi:10.1016/j.atmosres.2005.09.003, 2006.

Sutton, M. A., Burkhardt, J. K., Guerin, D., Nemitz, E., and Fowler, D.: Development of resistance models to describe measurements of bi-directional ammonia surface-atmosphere exchange, Atmos. Environ., 32, 473-480, doi:10.1016/S1352-2310(97)00164-7, 1998.

Sutton, M. A., Reis, S., Riddick, S. N., Dragosits, U., Nemitz, E., Theobald, M. R., Tang, Y. S., Braban, C. F., Vieno, M., Dore, A. J., Mitchell, R. F., Wanless, S., Daunt, F., Fowler, D., Blackall, T. D., Milford, C., Flechard, C. R., Loubet, B., Massad, R., Cellier, P., Personne, E., Coheur, P. F., Clarisse, L., Van Damme, M., Ngadi, Y., Clerbaux, C., Skjøth, C. A., Geels, C., Hertel, O., Wichink Kruit, R. J., Pinder, R. W., Bash, J. O., Walker, J. T., Simpson, D., Horváth, L., Misselbrook, T. H., Bleeker, A., Dentener, F., and de Vries, W.: Towards a climate-dependent paradigm of ammonia emission and deposition, Philos. T. R. Soc. B, 368, 20130166, doi:10.1098/rstb.2013.0166, 2013.

Takenaka, N., Soda, H., Sato, K., Terada, H., Suzue, T., Bandow, H., and Maeda, Y.: Difference in amounts and composition of dew from different types of dew collectors, Water. Air. Soil Pollut., 147, 51-60, doi:10.1023/A:1024573405792, 2003.

Takenaka, N., Takayama, K., Ojiro, N., Shimazaki, W., Ohira, K., Soda, H., Suzue, T., Sadanaga, Y., Bandow, H., and Maeda, Y.: The chemistry of drying an aqueous solution of salts, J. Phys. Chem. A, 113, 12233-12242, doi:10.1021/jp9054395, 2009.

Takeuchi, M.: Deposition of coarse soil particles and ambient gaseous components dominating dew water chemistry, J. Geophys. Res., 108, 1-5, doi:10.1029/2002JD003058, 2003.

Takeuchi, M., Hasegawa, T., Okochi, H., and Igawa, M.: Size distribution of dew droplets and dew formation effect on deposition fluxes, Bull. Chem. Soc. Jpn., 75, 1299-1300, doi:10.1246/bcsj.75.1299, 2002.

Wagner, G. H., Steele, K. F., and Peden, M. E.: Dew and Frost Chemistry at a Midcontinent Site, United States, J. Geophys. Res., 97, 20591-20597, 1992.

Walker, J. T., Robarge, W. P., Wu, Y., and Meyers, T. P.: Measurement of bi-directional ammonia fluxes over soybean using the modified Bowen-ratio technique, Agr. Forest Meteorol., 138, 5468, doi:10.1016/j.agrformet.2006.03.011, 2006.

Walker, J. T., Jones, M. R., Bash, J. O., Myles, L., Meyers, T., Schwede, D., Herrick, J., Nemitz, E., and Robarge, W.: Processes of ammonia air-surface exchange in a fertilized Zea mays canopy, Biogeosciences, 10, 981-998, doi:10.5194/bg-10-9812013, 2013.
Wentworth, G. R., Murphy, J. G., Gregoire, P. K., Cheyne, C. A. L., Tevlin, A. G., and Hems, R.: Soil-atmosphere exchange of ammonia in a non-fertilized grassland: measured emission potentials and inferred fluxes, Biogeosciences, 11, 5675-5686, doi:10.5194/bg-11-5675-2014, 2014.

Wesely, M. L.: Parameterization of surface resistances to gaseous dry deposition in regional-scale numerical models, Atmos. Environ., 23, 1293-1304, doi:10.1016/j.atmosenv.2007.10.058, 1989.

Whitehead, J. D., Longley, I. D., and Gallagher, M. W.: Seasonal and Diurnal Variation in Atmospheric Ammonia in an Urban Environment Measured Using a Quantum Cascade Laser Absorption Spectrometer, Water Air Soil Poll., 181, 317-329, doi:10.1007/s11270-007-9381-5, 2007.

Wichink Kruit, R. J., van Pul, W. A. J., Otjes, R. P., Hofschreuder, P., Jacobs, A. F. G., and Holtslag, A. A. M.: Ammonia fluxes and derived canopy compensation points over non-fertilized agricultural grassland in The Netherlands using the new gradient ammonia-high accuracy-monitor (GRAHAM), Atmos. Environ., 41, 1275-1287, doi:10.1016/j.atmosenv.2006.09.039, 2007.

Wichink Kruit, R. J., Schaap, M., Sauter, F. J., van Zanten, M. C., and van Pul, W. A. J.: Modeling the distribution of ammonia across Europe including bi-directional surface-atmosphere exchange, Biogeosciences, 9, 5261-5277, doi:10.5194/bg-9-52612012, 2012.

Wolfe, A. P., Van Gorp, A. C., and Baron, J. S.: Recent ecological and biogeochemical changes in alpine lakes of Rocky Mountain National Park (Colorado, USA): a response to anthropogenic, Geobiology, 1, 153-168, doi:10.1046/j.14724669.2003.00012.x, 2003.

Wyers, G. P. and Erisman, J. W.: Ammonia exchange over coniferous forest, Atmos. Environ., 32, 441-451, doi:10.1016/S13522310(97)00275-6, 1998.

Xu, Y., Zhu, H., Tang, J., and Lin, Y.: Chemical Compositions of Dew and Scavenging Particles in Changchun, China, Adv. Meteorol., 2015, 104048, doi:10.1155/2015/104048, 2015.

Yaalon, D. H. and Ganor, E.: Chemical Composition of Dew and Dry Fallout in Jerusalem, Israel, Nature, 217, 1139-1140, 1968.

Yadav, S. and Kumar, P.: Pollutant scavenging in dew water collected from an urban environment and related implications, Air Qual. Atmos. Health, 7, 559-566, doi:10.1007/s11869-0140258-7, 2014.

Ye, Y., Zhou, K., Song, L., Jin, J., and Peng, S.: Dew amounts and its correlations with meteorological factors in urban landscapes of Guangzhou, China, Atmos. Res., 86, 21-29, doi:10.1016/j.atmosres.2007.03.001, 2007.

Zhang, L., Wright, L. P., and Asman, W. A. H.: Bi-directional airsurface exchange of atmospheric ammonia: A review of measurements and a development of a big-leaf model for applications in regional-scale air-quality models, J. Geophys. Res.-Atmos., 115, D20310, doi:10.1029/2009JD013589, 2010.

Zhou, X., Civerolo, K., Dai, H., Huang, G., Schwab, J., and Demerjian, K.: Summertime nitrous acid chemistry in the atmospheric boundary layer at a rural site in New York State, J. Geophys Res.-Atmos., 107, 1-11, doi:10.1029/2001JD001539, 2002.

Zhu, L., Henze, D., Bash, J., Jeong, G.-R., Cady-Pereira, K., Shephard, M., Luo, M., Paulot, F., and Capps, S.: Global evaluation of ammonia bidirectional exchange and livestock diurnal variation schemes, Atmos. Chem. Phys., 15, 12823-12843, doi:10.5194/acp-15-12823-2015, 2015. 